\title{
Root Zone Management for Improving Seedling Quality of Organically Produced Horticultural Crops
}

\author{
Domenico Ronga $^{1, *(\mathbb{D}}$, Antonella Vitti ${ }^{1} \mathbb{D}$, Massimo Zaccardelli ${ }^{2}$, Catello Pane ${ }^{2} \mathbb{D}$, Federica Caradonia ${ }^{3} \mathbb{D}$, \\ Mariateresa Cardarelli ${ }^{2}$ (D), Giuseppe Colla ${ }^{4}$ (D) and Youssef Rouphael ${ }^{5}$ (D)
}

1 Pharmacy Department, University of Salerno, Via Giovanni Paolo II n. 132, 84084 Fisciano, SA, Italy; avitti@unisa.it

2 Consiglio per la Ricerca in Agricoltura e l'Analisi dell'Economia Agraria, Centro di Ricerca Orticoltura e Florovivaismo, 84098 Pontecagnano Faiano, SA, Italy; massimo.zaccardelli@crea.gov.it (M.Z.); catello.pane@crea.gov.it (C.P.); mteresa.cardarelli@crea.gov.it (M.C.)

3 Centre BIOGEST-SITEIA, Department of Life Sciences, University of Modena and Reggio Emilia, Via Amendola 2, 42122 Reggio Emilia, RE, Italy; federica.caradonia@unimore.it

4 Department of Agriculture and Forest Sciences, University of Tuscia, 01100 Viterbo, VT, Italy; giucolla@unitus.it

5 Department of Agricultural Sciences, University of Naples Federico II, 80055 Portici, NA, Italy; youssef.rouphael@unina.it

* Correspondence: dronga@unisa.it; Tel.: +39-339-6805848

\section{check for}

updates

Citation: Ronga, D.; Vitti, A.;

Zaccardelli, M.; Pane, C.;

Caradonia, F.; Cardarelli, M.;

Colla, G.; Rouphael, Y. Root Zone

Management for Improving Seedling

Quality of Organically Produced

Horticultural Crops. Agronomy 2021,

11,630. https://doi.org/10.3390/

agronomy11040630

Academic Editor: Alberto San

Bautista

Received: 23 February 2021

Accepted: 23 March 2021

Published: 26 March 2021

Publisher's Note: MDPI stays neutral with regard to jurisdictional claims in published maps and institutional affiliations.

Copyright: (c) 2021 by the authors. Licensee MDPI, Basel, Switzerland. This article is an open access article distributed under the terms and conditions of the Creative Commons Attribution (CC BY) license (https:// creativecommons.org/licenses/by/ $4.0 /)$

\begin{abstract}
Currently, vegetable production systems have been changed to improve yield and quality, leading to an improvement in sustainability. In horticultural cultivation, one of the most important sectors is the seedling production in nurseries. In the past, horticultural seedlings were produced directly by farmers. Nowadays, industrialized nurseries provide seedlings characterized by a uniform growth and an early and contemporaneous development. In addition, consumer concern about the impact of food production on the environment is driving an increased demand for organic vegetables with a consequent increase of agricultural land cultivated by organic methods. Hence, there is a need to produce high-quality seedlings suitable to be cultivated in the organic farming system. Root zone management, for improving seedling quality of organic horticultural crops, remains largely unexploited, such that this review highlights some of the current research and future development priorities, providing useful information to nursery growers. In particular, we reviewed all the scientific and modern knowledge on the production of organic, healthy and vigorous seedlings including the use of: (1) compost and compost tea; (2) agroindustrial byproducts; (3) microbial and non-microbial plant biostimulants; (4) beneficial microorganisms.
\end{abstract}

Keywords: compost; compost tea; organic fertilizer; plant biostimulant; biological control; transplanting; organic farming; high-quality seedlings; nursery

\section{Introduction}

Increasing current worldwide demand for organic food [1] is promoting research studies to obtain useful guidelines for improving organic farming sustainability. Nowadays, regarding horticultural production, farmers prefer transplant seedlings grown in a nursery, both in conventional and in organic farming systems. In modern agriculture, intensive seedling production is an essential segment, especially in horticultural production, to obtain high-quality seedlings [2]. In fact, specialized and industrialized nurseries can offer seedlings with high quality and uniform growth, more tolerant to abiotic and biotic stresses and with an early and contemporaneous development. In addition, seedling transplanting is advantageous in terms of saving energy, labor, time and seeds [3]. The cost of hybrid seeds is very important, and transplanting is an interesting method to reduce the number of seeds per square meter compared to direct sowing in the field. Nonetheless, nursery agronomic management can affect seedling quality and subsequently its field 
performance [4]. In a nursery, specific expertise and competence are required to produce high-quality seedlings within a short growing period (generally, up to the third-fourth true leaf stage) satisfying the farmer's requests in term of species, environmental adaptation, and tolerance to abiotic and biotic stresses.

Minami [5] reported that a farmer says: "A good seedling is 50\% of the production". In good seedling production, one of the most important aspects regards the achievement of a well-developed and functional root system [6] able to uptake water and nutrients and give a mechanical support to the seedling [7]. Frequently, farmers consider seedlings as a "root crop" to underline the significance of good-quality root system architecture [8]. However, in the nursery, root zone management to improve seedling quality, especially of organic horticultural crops, remains largely unexploited. Hence, the main objective of the present review is to highlight some of the current research and future development priorities to enhance the root zone management for improving seedling quality of organic horticultural crops (Figure 1).

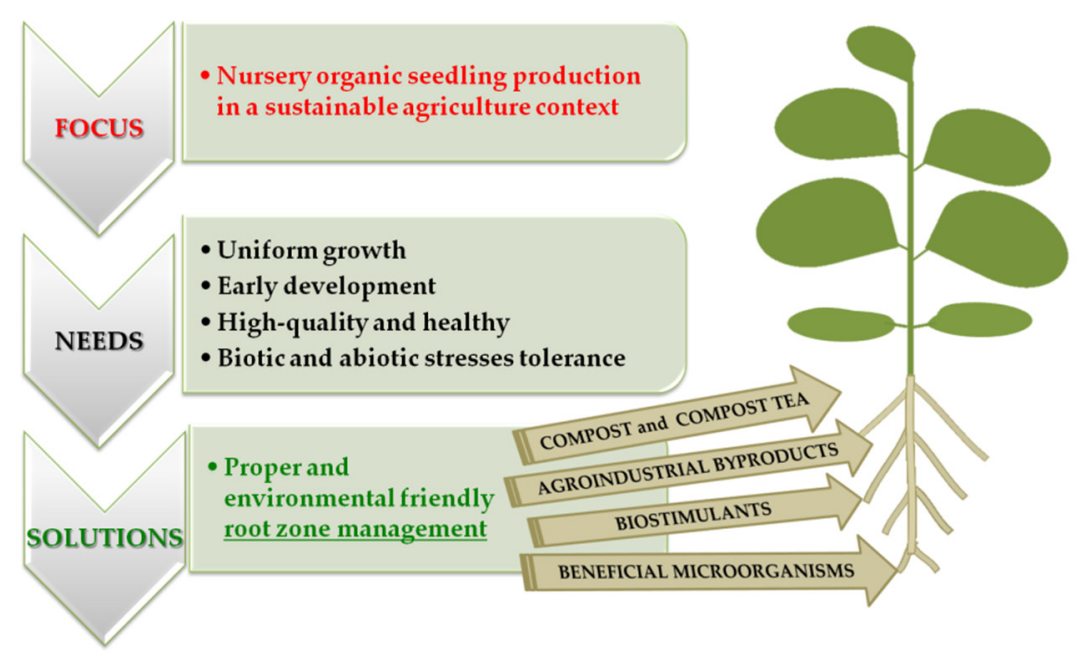

Figure 1. Root zone management for improving seedling quality of organically-produced horticultural crops.

In particular, this review explores four important and current topics about root management of horticultural seedlings: (i) compost and compost tea; (ii) agroindustrial byproducts; (iii) microbial and non-microbial plant biostimulants; (iv) beneficial microorganisms for biological control. All the information reported in the present review may allow the definition of specific guidelines for supporting nursery growers to improve the root management of seedlings suitable to be cultivated in organic farming system.

\section{Compost and Compost Tea to Produce Seedling in Nursery}

Compost is a well humified organic matter obtained by composting the undecomposed organic matter deriving from different feedstock. The compost process is accomplished by inhabitant microorganisms that generate more stabilized and mature molecular forms of organic wastes. Chemical and biological features, such as $\mathrm{pH}$, electrical conductivity, and microorganisms, influence the beneficial properties of compost [9]. Compost is a renewable resource that can contribute to reduce the peat rate in the growing media composition, improving their physical and chemical properties and providing suppressive effects against plant pathogens [10]. Meng et al. [11] recommended $20-50 \%$ as the right rate to replace peat with composted biogas residues and spent mushroom substrate, in order to cultivate tomato and pepper seedlings with better morphological traits. Spent coffee ground compost, used in a proportion up to $40 \%$, enhanced the general stand of basil and tomato seedlings by affecting dry weight, leaf area and biometric parameters [12]. However, compost effects are difficult to generalize, due to drawbacks associated with the content 
of salt and allelopathic compounds that may occur, partially solvable by modulating just the application rate [13]. Indeed, Carmona et al. [14] found that grapevine marc compost blended with peat-based medium only slightly affected the height and other parameters of growing lettuce, tomato, pepper and melon seedlings. However, the addition of municipal solid waste compost into peat, reduced pepper plugs morphological and physiological quality, although a priming effect on seed germination and rooting due to compost aqueous extracts was observed [15]. On the other hand, disease suppression activity of compost is the ability to affect the pathogenesis and reduce plant disease symptoms by co-operating with plant and pathogens in the telluric environment [16]. Therefore, suppressive composts have a preeminent field application in agroecological-based agricultural systems, aimed at strengthening the resilience and natural suppression of soils and growing media. In the nursery sector, they are particularly appreciated for decreasing disease incidences and dependence on synthetic fungicides in mixtures with peat as observed, for example, on Verticillium dahlie/eggplant [17], Fusarium oxysporum/cucumber [18]; Fusarium oxysporum f.sp. melonis/muskmelon [19] pathosystems. Mechanisms underlying compost suppression are essentially attributable to the microbiological components, since autoclaving can completely cancel all effects [20]; they act through antagonistic models configuring an overall effect measurable as enhanced microbial outcomes in terms of biomass and biodiversity [21], production of biocontrol-related enzymes [22] and triggering the immune response of plants [23]. Therefore, some biological parameters of composts would be able to predict the reaction to disease agents [24]. Metagenomics investigations are currently ongoing to decipher determinants of compost suppression at community levels [25,26]. De Corato et al. [27] found that suppression of Rhizoctonia damping-off and Fusarium oxysporum wilting by green composts, in container-amended media assay, was associated with population levels of the antagonistic fungus Trichoderma. In addition, this evidence prompted the use of promising composts in combination with microbial biocontrol agents, to enhance the suppressive results [28]. Other studies reported that some chemical properties, including $\mathrm{N}-\mathrm{NH}_{4}$ [29], lipid [30] and phenolic content [31], may reflect negatively effects on pathogenic communities by conferring to container media inhospitable conditions.

Composted chicken manure represents one of the traditionally soil improvers used due to its high content of organic matter and nitrogen $(\mathrm{N})$; however, the large and uncontrolled use of this material can lead to eutrophication of water bodies, spread of pathogens, plant phytotoxicity and emission of greenhouse gases [32,33]. Furthermore, issues occurring during the long-period-composting process, could be related to the initial characteristics of chicken manure substrate, having a low $\mathrm{C} / \mathrm{N}$ ratio, high moisture content, phytotoxic compounds, and an unpleasant odor [34]. To reduce these problems, an innovative composting process, using Hermetia illucens larvae, was evaluated in the management of chicken manure [34]. The larval frass obtained from a mixture of chicken manure, chabazite and water, was shown to have growing media improver properties able to sustain the production of baby-leaf lettuce, and demonstrating the possibility to be used as a substrate, if properly diluted, in a seedling nursery as well as in potted plant production [34,35].

In a recent study, the synergistic interaction between dewatering, composting and pelleting, was investigated to reduce the water content, harmful microorganisms and seed weeds in the organic fertilizers produced from livestock manure [36]. In particular, pelleting resulted in a drastic reduction of water content and harmful microorganisms in processed manure, also displaying a high nutrient availability, an improved water retention, and a reduced temperature of the growing medium. In addition, the combined effects of the three technologies reduced the total organic content, but maintained the most stable carbon, allowing a delocalization of the livestock manure from the production sites [36].

Compost tea (CT) is a liquid organic formulate obtained by extraction - from few hours to a week-of composted materials, with or without aeration during the process $[37,38]$. As extractive liquid, generally water is used, but other liquid extractants can be utilized, such as wastewaters from the food industry (whey, marc, molasses, etc.) with consequent different final composition of microbial populations of CT [39]. Quality of CT is determined 
by different factors, such as compost type, compost-to-water ratio and aeration level $[40,41]$. Microorganisms of the CT are mainly bacteria, but actinomycetes, yeasts and fungi contribute to define its properties, in particular biological control of plant pathogens and biostimulation of growth, physiological performances, and productivity of the plants [42-44].

CT applications as foliar spray or soil drenching can decrease plant disease severity $[39,45]$ involving different mechanisms mainly due to antagonistic microorganisms able to compete for space and nutrients, to produce antimicrobial compounds, to parasitize plant pathogens and to induce plant systemic resistance [46-48]. Moreover, nutrient and organic molecules such as humic and phenolic compounds, may protect the plants against diseases, by improving their nutritional status, by direct toxicity against the pathogens and by inducing systemic resistance into the plants [49]. In addition to plant protection mechanisms, several studies have indicated that cropping applications of CT may also improve yield and nutritional quality of the products [45,50-58].

CT supplies useful microorganisms, organic acids, plant hormone-like compounds and soluble mineral nutrients $[39,45,51]$. For these reasons, CT is proposed as a sustainable alternative to synthetic inputs for enhancing plant nutrition, protection, growth and productivity $[59,60]$, with consequent positive effects on human health and the environment [61].

Several studies report the use of CT on crops cultivated in open fields or in greenhouses, with very interesting results on disease control and yield, emphasizing benefits due to their use as organic additive in plant cultivation and in the suppression of soilborne diseases $[37,58]$. By contrast, very limited results are reported on the use of CT in nursery systems.

In a vegetable nursery, one of the most used synthetic fungicides is Previcur Energy ${ }^{\circledR}$, that combines propamocarb and fosetyl-Al to control Pythium spp., and is also able to develop seedlings tolerance to Phytophthora spp. and a general stimulation of plants self-defense systems [62,63]. Recently, Villecco et al. [64] demonstrated that it is possible to partially replace Previcur Energy ${ }^{\circledR}$ with CT on tomato, pepper and melon seedlings cultivated in a nursery. Bernal-Vincente et al. [59] investigated two different types of CT obtained by citrus composts on melon seedlings in greenhouse nurseries. Both CTs demonstrated a biocontrol effect against Fusarium oxysporum for melon seedlings and no different bacterial biocontrol efficacy was observed between both CTs.

Restrictive legal limits about the use of agrochemicals, have stimulated researchers to work for making available new eco-friendly methods for both plant fertilization and diseases control, such as natural bioactive compounds and beneficial microorganisms. The use of CT seems to be a valid method to reduce agrochemicals not only in crop cultivation, but also in crop nurseries. In particular, the reduction of pesticides in a vegetable nursery is a necessary practice to gain the goals of sustainability in this sector. In this view, organic matter-based natural products are a valid alternative to replace agrochemicals, due to their bioefficacy, circular economy character, and negligible impacts on water and wildlife [60].

\section{Valorization of Agroindustrial Byproducts in Innovative Organic Fertilizers and Growing Media Suitable for Seedling Production}

Root growth and its architecture are affected by several factors, showing different performance when crops are cultivated in an open field or greenhouse. In addition, nurseries seedling production is characterized by a very short growing season, and seedling roots can explore a relatively small volume of growing medium. The consequent demand of specific nutrients means that the adoption of definite and efficient fertilization strategies, even more so in the organic nurseries, is extremely important. For example, $\mathrm{N}$ management requires organic fertilizers to be mineralized by microorganisms in order to become available for plant uptake $[10,65]$. In this regard, organic fertilizers are characterized by a slow release of nutrients, especially $\mathrm{N}$, due to the rate of net $\mathrm{N}$ mineralization from solid organic fertilizers, which can vary in a different way (slow to fast) depending mainly on the $\mathrm{C} / \mathrm{N}$ ratio. Environmentally friendly fertilizers produced using agricultural byproducts have been developed in order to improve yields and without compromising the environment 
sustainability. In addition, organic fertilizers are able to provide organic matter, improve growing media fertility and reduce nutrient loss by retarding, or even controlling, the release of nutrients into growing media [66].

The current European action plan for the Circular Economy [67], together with the Bioeconomy Strategy [68] strongly incentivize the valorization of biowaste in resources. In this perspective, the European Union (EU) Regulation 2019/1009 establishes rules to make available fertilizer on the EU market, promoting biowaste recycling to produce sustainable fertilizer based on plant byproducts or plant extracts [69].

In the last decades, the anaerobic digestion (AD) process has gained great interest for the production of green energy. One of the byproducts obtained from AD is digestate [70] that recently has been exploited in agriculture as an innovative and sustainable fertilizer [71,72]. In fact, during anaerobic digestion, $\mathrm{N}$, phosphorous and potassium, present in the feedstock, are retained in the digestate [73].

Humic-like substances are considered as fundamental biological active components of digestate. Natural humic-like and plant hormone-like substances were extracted from digestate using micro- and ultra-filtration, considered useful raw materials for organic fertilizers, and used as extra root feeding [74].

The application of digestate coming from anaerobic fermentation of swine manure have been considered on crops and horticultural plants under different agricultural practices and in greenhouse conditions $[75,76]$. The authors indicated that concentrations of liquid digestate between $2 \%$ and $3 \%$ stimulated seed germination, whereas it can be applied even at $20-30 \%$ during more advanced growth stages.

Ronga et al. [77] evaluated the effects of solid and liquid digestate as an alternative and sustainable growing medium and nutrient solution in the hydroponic cultivation of baby leaf lettuce (Lactuca sativa L.) by studying nine different hydroponic combinations of substrate and fertilizer in which solid and liquid digestates were used alone or together. The researchers indicated that the combined use of agriperlite (as growing medium, GM) with liquid digestate (as fertilizer, F), solid digestate (as GM) with standard solution (as F), and pelleted digestate (as GM) with standard solution (as F) displayed sustainable and alternative growing media or nutrient solutions able to enhance baby leaf lettuce growth, in turn positively affecting different parameters like root, shoot and total dry weights and SPAD index [77]. In another, study solid and liquid digestates were evaluated for the soilless production of basil and peppermint seedlings in the replacement of agriperlite and synthetic fertilizers, respectively [78]. The authors reported that the use of solid digestate as growing media and liquid digestate as fertilizer can represent a sustainable agronomic practice to valorize byproducts of biogas plants, when used in soilless production.

Greco et al. [79] demonstrated that solid digestate, can be used as valid alternative to peat for sage cultivation, when used at $40 \%$ for preparing the growing substrate.

Recently, it has been demonstrated that the good fertilizing properties of digestates sometimes may be lost if it is not completely stabilized. In order to overcome this problem, a post-treatment consisting in a further composting process could transform the digestate to a mature, stable, safe, and nutritive compost [80]. For example, very recently, it has been proven that a further maturation process of a cow slurry digestate produced more stabilized digestate-derived compost. It was able not only to increase the growth of potted seedlings, but also to induce a damping-off suppression caused by Fusarium solani in tomato plants, when added to soil at 5\% and 10\% [81]. Innovative studies about captured fish waste-derived compost and digestate from anaerobic digestion/co-digestion were considered; the applicability of such fertilizers in organic farming was evaluated [82] and biostimulant effects were reported on the growth of lettuce [83].

Agricultural wastes, such as forestry, crop residues and animal manures can be transformed to obtain biochar [84] that represents a byproduct of thermal pyrolysis [73]. Monterumici et al. [85] indicated that when the biochar is used as amendment, a stable carbon pool can be stored. Studies in the last decade have mainly focused on biochar application as a soil amendment and for soil remediation, as well as the possibility of its successfully addi- 
tion in the composting processes of various agricultural waste [86]. In fact, several studies are consistent with the use of biochar combined with other products. Kaudal et al. [87] demonstrated that some properties such as density, $\mathrm{pH}$, and $\mathrm{C} / \mathrm{N}$ ratio of growing media, increased in a proportional manner to the biochar rate used in mixtures with composted pine bark.

Various studies have been done on the use of vermicompost as innovative growing media [88]. Atiyeh and co-authors [89] reported the first research about the beneficial use of vermicompost on the first stages of plants emergence and development. They demonstrated that the growth of marigold and tomato seedlings was enhanced using vermicompost, obtained from pig slurry or food waste, by up to $20 \%$ as growing media.

Several studies reported the innovative and successful use of spent coffee ground (SCG) in the production of innovative and sustainable biofertilizers [12,90,91]. An innovative application for SCG has concerned its use as filler for the formulation of lightweight clay ceramic aggregates for agricultural purposes [90]. More recently, the same SCGs were used alone or together with biochar as pore-forming agents in the realization of these lightweight clay ceramic aggregates and then used as sustainable fertilizers [91]. However, further studies are needed to confirm their agronomic performance on horticultural seedlings cultivated in nursery.

The first use of black soldier fly larvae processing residue as an innovative ingredient for growing media has been evaluated in the production of baby leaf lettuce, basil and tomato seedlings [35]. The study indicated that up to $20 \%$ black soldier fly larvae processing residue increased crop growth in terms of total dry weight, leaf number and leaf area without inducing any abiotic stress, demonstrating the feasibility of using black soldier fly as an interesting alternative for recycling and valuing agro-industrial by-products, and as an innovative ingredient for partially replacing commercial peat-based growing media able to provide nutrient to plants [35].

Among innovative organic fertilizers, microalgae biomasses have been investigated due to their ability to prevent nutrient losses through a gradual release of macro and micro-nutrients $[92,93]$. Several studies highlighted the beneficial effects of microalgae when used as biofertilizer: greater nutrient uptake, higher biomass production, and higher crop yields were displayed [94-96]. Hence, these products might be assessed also for the production of horticultural seedlings cultivated under an organic system.

Ciavatta et al. [97] reported that blood meal is an organic fertilizer containing interesting value of organic $\mathrm{N}$ about $10-13 \%$. The authors displayed that about $75 \%$ of the organic carbon and of the organic $\mathrm{N}$ were mineralized in soil, while the remaining carbon was converted into humified compounds. In addition, the availability of the iron and its successive chelation in the humic substances increased after the soil application. Bae et al. [98] demonstrated that blood of livestock can be used as a sustainable fertilizer, instead of the synthetic fertilizer used to produce environment-friendly organic seedlings. The authors reported that the application of blood as fertilizer increased the number of leaves of hot pepper and tomato compared to the use of synthetic fertilizer. In future research, these results on the adoption of blood as sustainable fertilizer might be validated also for the production of horticultural seedlings.

\section{Implications of Microbial and Non-Microbial Biostimulants for Seedling Quality}

According to the Regulation (EC) N. 2019/1009 of the European Parliament and Council, microbial biostimulants include arbuscular mycorrhiza fungi (AMF) and plant growth-promoting rhizobacteria (PGPR) belonging to the genera Azotobacter spp., Azospirillum spp. and Rhizobium spp. [99-101]. Both mycorrhizal fungi and rhizobacteria have a phytostimulation effect on plants through mobilization of soil nutrients, control of hormonal and nutritional balance in plants, and secretion of plant growth regulators and signal molecules [102-106]. Their effectiveness has been documented by numerous research projects that have highlighted different results depending on the interaction between a specific species (or strain) of fungus and a defined vegetable crop (or cultivar). Even 
the inoculation method and the growing conditions influence the biostimulant effect on crops $[107,108]$. For instance, external seed treatments and early applications on seedling by soil inoculations, facilitate the microbial development in the rhizosphere, promoting interaction with the host plant. Recent research has focused on different vegetable seedlings applying AMF on seed before sowing. Watermelon seeds inoculated with Rhizophagus intraradices and germinated in nursery conditions showed seedlings with higher dry matter and with a root system more developed than non-inoculated seedlings [109]; inoculated seedlings revealed an increase of secretory purple acid phosphatase (PAP) genes expression and APase activity in rhizosphere soil (at the root surface) in comparison with the control, and an enhancement of phosphorus concentration in seedlings. Rhizophagus intraradices has been effective in onion seedlings inducing an increase of $35-40 \%$ more total biomass than the control (increased shoot and root dry matter) even if the percentage of mycorrhizal colonization in onion roots never exceeded 20\% [110]. Tomato seedlings showed more leaves in response to inoculation with Rhizophagus irregularis compared with non-inoculated seedlings [111]. Research in greenhouses comparing different mycorrhiza species (Glomus mosseae, G. clarum, G. caledonium, G. intraradices and G. etunicatum) or their mixture for inoculation of eggplant revealed more vigorous seedlings before transplanting to field conditions and a significantly higher P and Zn uptake [112]. Glomus intraradices, G. etinucatum, and Gigaspora margarita increased the nutrient uptake in different zucchini hybrids cultivated in a growth chamber [113].

There has been great interest in interactions between mycorrhiza species and plants under abiotic stress conditions. According to Ronga et al. [114] the fungus Funneliformis mosseae was more effective than Rhizophagus intraradices for sustaining the growth of tomato seedlings under reduced water regime and also Funneliformis mosseae increased the chilling tolerance of tomato seedlings cultivated at $8{ }^{\circ} \mathrm{C} / 4{ }^{\circ} \mathrm{C}$, day/night [115] and similar results were reported by Caradonia et al. [116] in cropping processing tomato at $1{ }^{\circ} \mathrm{C}$. AMFinoculated tomato seedlings showed higher biomass than control seedlings regardless of the presence of chilling stress but, under low temperature, AMF inoculation has boosted redox poise and antioxidant potential, as confirmed by a reduced lipid peroxidation of the plasma membrane and an efficient neutralization of $\mathrm{H}_{2} \mathrm{O}_{2}$, along with increased calcium precipitates in the apoplast and vacuole of root cells compared with the non-AMF control [115]. Watermelon seedlings are very sensitive to chilling stress, with significant alterations in chlorophyll content and electrolyte leakage, but the inoculation with Rhizophagus irregularis (previously known as Glomus intraradices) was effective by restoring the photosynthesis efficiency, reducing the oxidative stress with a lower accumulation of $\mathrm{H}_{2} \mathrm{O}_{2}$ and malondialdehyde and an increase of root and shoot dry matter [117]. Instead, Turkmen et al. [118] treated pepper seedlings with moderate salinity stress ( $75 \mathrm{ppm} \mathrm{NaCl})$ and demonstrated how Rhizophagus irregularis and Gigaspora margarita were able to relieve the stress with respect to the growth and nutrient contents of seedlings.

With regard to rhizobacteria effects on vegetable seedlings, some scientific data are available for both Azotobacter and Azospirillum or Rhizobium. In a greenhouse pot experiment, Azotobacter sp. strain AC11 was able to promote the growth of tomato seedling (shoot height, root length, dry and fresh weight) and to increase chlorophyll, soluble protein and soluble sugar content by fixing $\mathrm{N}$, solubilizing potassium and phosphorus, and by producing indole-3-acetic acid (IAA) and siderophores [119]. The same strain induced a significant resistance to salt stress of tomato seedlings through the promotion of antioxidant enzymes (superoxide dismutase (SOD), peroxidase (POD), and catalase(CAT)) and an increase of osmotic substances (soluble sugars and proteins) [119].

Azospirillum is known for the ability to affect early growth of different vegetable crops. Lettuce, tomato and cucumber seeds inoculated with three Azospirillum brasilense strains (i.e., Sp7, Sp7-S and Sp245) and using different inoculation methods (soaking or drenching before and after sowing), showed bacterium strain [differently able to produce IAA] and plant species, significantly differed in their effect on root and shoot growth of seedlings [120]; both emergence and seedling vigor were influenced by inoculation method 
and Azospirillum strain whose IAA synthesis stimulated a faster emergence of healthy embryonic growing axis [120]. A. brasilense increased biomass of lettuce seedlings only in the presence of salinity stress during the germination [121], whereas in tomato the bacteria inoculation induced a stem and root elongation with and without salt stress [122]. Interesting results have been obtained considering $\mathrm{N}_{2}$-fixing rhizobia for inoculation of vegetable plants. Seed treatments with Rhizobium leguminosarum promoted seedling quality of Brassica campestris, B. napus and Lactuca sativa by increasing early seedling root growth [123], and the co-inoculation of Rhizobium tropici (CIAT 899) with selected nodule endophytic strains of Bacillus, Paenibacillus, Burkholderia, and Pseudomonas on common bean plants grown in greenhouses can replace any sub-optimal $\mathrm{N}$ availability for seedlings [124].

In addition to microbial plant biostimulants, the use of non-microbial plant biostimulants such as humic acid, macro and microalgal extracts, protein hydrolysates, chitosan and silicon are considered as sustainable and efficient tools to improve vegetable seedling quality and post-transplant performance under both optimal and sub-optimal conditions. In particular, Piccolo et al. [125] reported the application of unfractionated humic acids (applied at 40,100, 1000 or $5000 \mathrm{mg} / \mathrm{L}$ ) and humic fractions (applied at 40, 100 or $200 \mathrm{mg} / \mathrm{L}$ ) did not increase either the germination rate, or the germination percentage of lettuce and tomato seeds treated in Petri dishes. However, the growth seedlings parameters of both tested species, increased in treatments with unfractionated humic acid without reporting any signs of inhibition even at the highest dose $(5000 \mathrm{mg} / \mathrm{L})$. The authors concluded that the beneficial effects of humic substances on seedlings quality were associated with cell elongation, as well as with a better water uptake. Similarly, Lulakis and Plestas [126] showed that the intermediate concentrations (100-300 ppm) of humic substances extracted from vine canes mature compost, boosted the tomato seedling growth (in terms of plant height) whereas an inhibitory effect was observed at higher concentrations (1000-2000 ppm). Young and Chen [127] attributed the biostimulation action of humic acid on lettuce seedlings to the presence of polyamines (putrescine, spermine and spermidine) which are responsible for the hormone-like activities of humic substances. Moreover, the humic acid application as seed priming $(5000,10,000$ or $20,000 \mathrm{mg} / \mathrm{L})$ or substrate drench $(2500$ or $5000 \mathrm{mg} / \mathrm{L})$ promote seed root development (in terms of lateral root growth and number) in both cucumber and squash [128]. The increase of root growth in humic acid-treated plants could be adopted as an efficient and sustainable strategy and enhance stand establishment in commercial applications such as plug production. Furthermore, the biostimulant action of humic acid on seedling growth of two important vegetable species, such as tomato and eggplant, was investigated by Dursun et al. [129]. The authors demonstrated that substrate drench application exhibited the highest leaf stem (at 50 and $100 \mathrm{~mL} / \mathrm{L}$ ) and root growth (at 50, 100 or $150 \mathrm{~mL} / \mathrm{L}$ ) for tomato and eggplant seedlings, respectively compared to the untreated control, by improving macro and micronutrients $(\mathrm{N}, \mathrm{P}, \mathrm{K}, \mathrm{Ca}, \mathrm{Mg}$, Fe and $\mathrm{Cu}$ ) uptake and translocation, leading to a better nutritional status. The use of lignite derived solid humic substances (32\% humic acids, 3\% fulvic acid and $24 \%$ humin) as media amendment was also found effective to improve vegetables (lettuce, pepper, tomato and watermelon) seedling quality and post-transplant performance under optimal and sub-optimal conditions (drought and heat stress; [130]). The application of humic acid modulated the shoot and root growth parameters in a species-dependent manner. The root traits were significantly increased in fruit-treated vegetables, whereas the highest leaf performance was recorded in the leafy vegetable tested (i.e., lettuce). Although drought and heat stresses had negative impact on yield of the four vegetables tested, however, the humic acid-treated plants showed improved stress tolerance/avoidance compared to the untreated control.

Concerning the application of macro and microalgal extracts on seedlings quality, several authors [131-133] have demonstrated the biostimulation action of this important category of plant biostimulant which constitute more than one third of the total market [134]. A biostimulant product based on kelp extract (Durvillaea potatorum and Ascophyllum nodosum), applied at weekly intervals at a concentration of $4 \%, 1 \%, 0.5 \%$ or $0.2 \%$, enhances 
greenhouse broccoli establishment and growth by boosting shoot biomass, stem diameter and leaf area by $145 \%, 65 \%$ and $75 \%$, respectively, compared to untreated plants [131]. Moreover, the foliar or drench application of two green (Ulva lactuca and Caulerpa sertularioides), and two brown (Padina gymnospora and Sargassum liebmannii) seaweed extracts at different concentrations $(0.2,0.4$ or $1.0 \%)$ were assessed under controlled conditions on tomato seedlings [133]. The authors reported that specific seaweeds, such as U. lactuca and P. gymnospora, were the best to stimulate the tomato germination and seedlings quality (higher shoot and root length and weight) when they were applied at lower concentrations (i.e., $0.2 \%$ ). The authors also demonstrated that soil drench application should be adopted among vegetable growers, since it was able to enhance tomato plant height, compared to the foliar application treatment. These results might be validated also on horticultural seedlings cultivated in a nursery under an organic system. In line with the previous research, the radical application of microalgae strains Scenedesmus quadricauda positively affected the growth of lettuce seedlings grown on an inert substrate, such as pumice. The authors showed that the application of microalgae two times during the growing cycle resulted in an increase in: (i) dry matter percentage and proteins content; (ii) carotenoids and chlorophyll chloroplast pigments; (iii) enzyme activities of glutamate synthase, cytrate synthase and phenylalanine ammonia lyase.

Thanks to the combination of morphological and metabolomics approaches, Lucini et al. [135] and Kim et al. [136] elucidated the hormonal effects of a vegetal-based biostimulant (containing lignosulfonates, key amino acids and peptides as well as micronutrients) on melon and tomato. In both experiments brassinosteroids and stress related compounds (carotenoids, flavonoids and glucosinolates) triggered in roots may have been involved in modulation of root system architecture by improving adventitious rooting responses observed after biostimulant root application, thus enhancing tolerance/resistance toward plant stress (i.e., transplant shock).

In another interesting study, non-microbial biostimulants based on chitosan microparticles improved both shoot and root biomass of tomato seedlings, reinforcing their performance before transplanting [137]. The contribution of chitosan microparticles seems more effective on: (i) the modulation of cytokinin and auxin hormonal signaling pathways; and (ii) the stimulation of the antioxidant enzyme activities CAT and SOD and defense protein markers. Finally, Bu and co-workers [138] demonstrated the beneficial effect of exogenous application of silicon under optimal and especially autotoxic (3-phenylpropionic acid) induced stress in cucumber seedlings by boosting the relative activities of key enzymes such as ascorbate peroxidase (APX), CAT, POD and SOD combined with the protection of the cell wall and membrane integrity (by reducing the $\mathrm{O}_{2}{ }^{\bullet-}, \mathrm{H}_{2} \mathrm{O}_{2}$ and proline contents and the percentage of electrolyte leakage).

Although several efforts have been carried out in the field of microbial and nonmicrobial plant biostimulants, more research is needed to elucidate the physiological, biochemical and molecular mechanisms/mode of actions in relation to their composition, application time, concentrations, environmental conditions and species, in order to develop a second generation of functional biostimulants with specific biostimulatory action(s).

\section{Beneficial Microorganisms for Biological Control of Seedling Diseases}

Damping-off, seedling blight, wilt and root rot diseases significantly decrease the quality of young seedlings of many horticultural crops such as cucumber, tomato, pepper, melon, eggplant, lettuce, etc. $[139,140]$. The common pathogens responsible for the spread of these diseases belong to fungi and bacteria of genera Fusarium, Rhizoctonia, Verticillium, Sclerotium, Pythium, Xanthomonas, Ralstonia solanacearum, etc. [140-142]. In the nursery, the spread of these pathogens is due to the use of infected potting media/trays, recycled irrigation water, or infected seeds [140]. Also, the intensification of nursery production, causing high moisture and nutrient supplies, can promote occurrence and spread of root zone pathogens [143]. 
Generally, in the nursery, pathogens are controlled by an intensive use of plant protection products [140]. However, in an organic system, pathogen management of root zone is based on the use of preventive measures such as certificate and resistant plant materials, endpoint inspections and quarantines [144]. When preventive measures are not enough to control pathogens, plant protection products may be applied. At the moment, the active substances registered for use in the nursery for an organic system against root zone pathogens belong mainly to microorganism groups also known as biological control agents (BCAs).

New BCAs are isolated from different substrates such as soil, vegetable material, compost, peat, etc. $[145,146]$. The BCAs can be applied alone or in consortia directly on seeds, sprayed to soil or used to enriched peat and compost. BCAs can able to establish antagonistic interactions against pathogens through specific mechanisms, such as parasitism, antibiosis or competition for nutrients or sites of infection and/or, indirectly, inducing the host plant's defenses [147]. These properties can be exploited in the management of nursery diseases [148]. Biocontrol definition also includes the use of living natural enemies of pathogens, and/or their products such as antibiotics, secondary metabolites, lytic enzymes, etc. [149]. The main potential BCAs studied belong to antagonistic fungal groups, such as Trichoderma spp., arbuscular mycorrhizal fungi and bacteria, such as Bacillus spp. and Pseudomonas spp. [150,151].

Trichoderma spp. are ubiquitous and free-living fungi that are among the most wellknown and globally commercialized biocontrol fungi for agricultural applications. Their winning strategy relies on the exploitation of different mechanisms of action [152], strong rhizosphere competence [153] and endophytic status [154]. In the vegetable nursery sector, Trichoderma antagonistic strains may have versatile uses ranging from growing media bioactivation to the direct suppression of pathogens administered by drenching $[155,156]$ and/or spraying [157]. Trichoderma contribute both to health management, reducing dependence on chemical fungicides, and to an increase of seedling quality associated with growth promotion [158]. Several plant protection biocontrol studies have confirmed the effectiveness of Trichoderma spp. in increasing tolerance against pathogenic fungi, bacteria and viruses. The increased tolerance was due to several mechanism of action such as mycoparasitism, the induction of hypersensitive response (HR), systemic acquired resistance (SAR) and/or induced systemic resistance (ISR), effects on plant nutrient condition, changes in plant transcripts by plant gene modulation, competition for nutrients and space, fungistasis, antibiosis and modification of the rhizosphere [159-161].

On a set of Solanaceous and Brassicaceous vegetable seedlings, T. viride, T. harzianum, and T. koningii, applied as seed treatment, proved to be able to control Pythium aphanidermatum, as well as the synthetic fungicides [162]. T. virens, T. harzianum and T. asperullum selected strains enrich organic media and effectively enhance the growth of Abelmoschus esculentus and Amaranthus viridis [163]. Nursery management with T. harzianum improved eggplant seedling performance and reduced damping-off disease [164] giving a significant advantage to the improved seedlings in the successive transplant [165].

A study on a single treatment with T. harzianum strain T22 on seeds of tomato (genotype 'Jubilee'), exposed to Pythium ultimum, reported that the seed treatment avoided losses $(-15 \%)$ due to post-emergence damping-off [166].

Combined inoculation resulted in a general synergistic effect on disease control. Gilardi et al. [141] tested some Trichoderma strains in consortia to reduce the severity of Fusarium wilt in lettuce (genotype 'Crispilla') and rocket (genotype 'Coltivata'). The BCAs were applied four times by spraying the soil in each plug tray with a high volume of water $(1800 \mathrm{~L} / \mathrm{ha})$. The treatments reduced the spread of disease compared to the untreated control, with an average efficacy of $40 \%$ in both crops. Synergistic effects on control of Fusarium wilt incidence were found also in inoculations of T. harzianum combined with arbuscular mycorrhizal fungi, such as Rhizophagus intraradices, Funneliformis constrictuson and Claroideoglomus claroideum, on Giotto melon (C. melo L.) [167]. Pascual et al. [28] has 
studied the use of T. harzianum T-78 to enrich compost reporting a lesser pathogen incidence (Fusarium oxysporum f. sp. melonis) on muskmelon seedlings (genotype 'Giotto').

Beyond the Trichoderma group, research is proposed for the biocontrol of other fungi such as Coniotirium minitans, non-pathogenic Fusarium oxysporum and the oomycete Pythium oligandrum. C. minitans is a specific hyperparasitic fungus: it feeds on the sclerotia of Sclerotinia spp. For this reason, it is very useful in the defense of lettuce and other species susceptible to this rotting agent [168]. On the other hand, recent studies focused on the biocontrol ability of non-pathogenic F. oxysporum strains, resulting in the reduction of phytopathogenic attacks by occupying the infection sites or by triggering the immune response in the plant [169]. P. oligandrum is also proposed for the protection of nursery vegetables from the attacks of some of the most feared soil pathogens; it exerts antagonistic action through competition and production of enzymes and antifungal metabolites [170,171].

Other than fungi, bacteria can be used as a plant growth stimulator (plant growth promoting rhizobacteria, PGPR) or for controlling plant disease (biocontrol agents, BCA) [172-177]. These useful bacteria are largely used in agriculture, both in open field and in greenhouse [178-182]; they also can be used in nursery to improve growth and protect seedlings. The increasing application of useful bacteria in agriculture is due to the growing public demand for organic and chemical-free foods and for the recent restrictive regulations about the use of agrochemicals to reduce negative effects on environment and human health [183] and to reduce the development of pathogen resistance, due to repeated use of agrochemicals [184].

Bacteria used as PGPR and BCA principally belong to Pseudomonas and Bacillus genera [185-192]. Several authors have described the ability of many Pseudomonas spp. and Bacillus spp. rhizosphere strains to promote plant growth and control a plethora of fungal plant pathogens. Plant growth promotion is due to different mechanisms, such as biosynthesis of IAA, cytochinins or gibberellins [193-197], the induction, in planta, of these phytohormones or repression of synthesis of phytohormones that promote plant senescence, such as ethylene [194]. Other mechanisms that can promote plant growth are nitrogen-fixing or phosphate solubilizing properties of some strains $[198,199]$. Disease control is due to different direct mechanisms such as antibiosis, competition for nutrients and space, production of siderophores and toxic volatile compounds [200-208] and by indirect mechanisms, such as the activation of ISR [209-214]. In many cases, BCA have plant growth promotion properties as they can reduce density, on the roots, of phytopathogenic and deleterious bacteria $[215,216]$ by the aforementioned mechanisms.

Among bacteria used in agriculture, Bacillus spp. are particularly suitable for commercial purposes. In fact, they are able to produce endospores, structures that confer resistance to desiccation, higher temperature and extreme $\mathrm{pH}$ and osmotic conditions, allowing bacterial cells to overcome adverse environmental situations.

Regarding BCAs based on bacteria, Sahu et al. [217] found that tomato seeds (genotype 'Selection-22') inoculated with endophyte Bacillus sp. 2P2 showed protection against Sclerotium rolfsii by reducing disease incidence by $67 \%$ in a nursery. The authors ascribed the activities of the antagonistic bacteria both to the inhibition of growth of $S$. rolfsii and induction of systemic resistance in seedlings. Paenibacillus polymyxa applications (BIO formulation) in the seedling nursery soil resulted in the lowest Fusarium wilt disease incidence on watermelon [Citrullus lanatus (Trunb.) Matsum and Nakai] genotype 'Kangbing Jingxin' with an average biocontrol efficacy of 55\% in comparison with untreated control [218].

Bacteria could be good antagonists against bacteria pathogens such as Ralstonia solanacearum and Xanthomonas spp. A previous study, in fact, showed as Pseudomonas putida A1 delayed wilt symptoms for 4 days and reduced disease severity [146].

The success of the biological control agents depends on many different factors, including the pathogen infestation level and the type of inoculum [219]. Also, the formulation of BCAs can play a key role in the effectiveness of products [220] as it can influence the survival of microorganisms on peat [221]. In the latter study [221], the authors reported 
that, after 8 weeks, a formulated form containing oat, bentonite, vermiculite and water, kept the inoculation level of T. harzianum colony-forming units two times higher than the non-formulated T. harzianum inoculum in nursery plants grown in polystyrene containers. Bernal-Vicente et al. [222] assessed different types of solid (bentonite, vermiculite, river sand and wheat bran) and liquid (water, guar gum, carboxymethylcellulose) carriers for application of Trichoderma harzianum T-78 for improving its peat survival and promoting biocontrol activity against Fusarium wilt of melon in seedling nursery conditions. The liquid carrier was incorporated directly into the peat or used to soak seeds, whereas the solid carriers were mixed homogeneously with peat or superficially applied. Interestingly, the most effective treatments that gained the lowest percentage of infected plants and the greatest $T$. harzianum population were the solid treatments based on bentonite mixed with peat or vermiculite superficially applied, partially confirming the results obtained by Martínez-Medina et al. [221].

\section{Conclusions}

To improve nursery sustainability, a reduction of external inputs, especially in terms of synthetic fertilizers, pesticides and fungicides is required. From this point of view, an organic farming system might be an interesting sector to improve food quality and nursery sustainability. In horticultural production, a high quality of seedling is a goal. In fact, farmers require a seedling with high quality to overcome transplanting stress in a shorter time. In addition, seedlings with high quality are characterized by tolerance to abiotic and biotic stresses, guaranteeing high yield and good quality of the harvest products. These concepts are fundamental, especially for seedlings suitable to be cultivated under organic farming systems, where synthetic products are not allowed to overcome abiotic and biotic stresses. Until now, not much research has dealt with issues related to horticultural seedlings and only few studies have analyzed the organic production of seedlings in nurseries. Several strategies to improve the sustainable root zone management of seedlings grown in nurseries, are presented in the present review. All this information might allow the definition of precise protocols for helping nursery growers in the production of seedlings suitable to be cultivated in organic farming systems and in the correct applications of the strategies here reported. However, physiological, environmental, genetic and agronomic factors can form a complex network of interactions and synergies contributing to influence root growth of the seedlings.

\section{Future Directions}

Most nursery growers are worried about the future, and they not only aim to modernize equipment, but are interested in "what can happen tomorrow". In fact, legislation, business and crop tendencies, new technologies and products, politics and environmental changes are all aspects to be considered. The nursery growers have to be prepared for the new changes, and this review aims to provide useful information on current opportunities and future directions on root zone management for improving seedling quality of organically produced horticultural crops. Some interesting key parameters should be monitored by nursery growers and investigated by researchers like: (i) architectural root traits (rooting depth and root length density); (ii) morphological root traits (root diameter and specific root length); and (iii) physiological root traits (root respiration, root nutrient uptake, root exudates). Finally, further studies with a multi-disciplinary approach are required to understand the seedlings' root growth in terms of its integrity, allowing the development of new and sustainable strategies effectively able to increase the sustainability of organic production of vegetable seedlings in nurseries.

Author Contributions: Conceptualization, D.R. and Y.R.; writing—original draft preparation, D.R., A.V., M.Z., C.P., F.C., M.C., G.C. and Y.R.; writing-review and editing, D.R., A.V., M.Z., C.P., F.C., M.C., G.C. and Y.R. All authors have read and agreed to the published version of the manuscript.

Funding: This research received no external funding. 
Institutional Review Board Statement: Not applicable.

Informed Consent Statement: Not applicable.

Data Availability Statement: No new data were created or analyzed in this study. Data sharing is not applicable to this article.

Conflicts of Interest: The authors declare no conflict of interest.

\section{References}

1. Greene, C.; Ferreira, G.; Carlson, A.; Cooke, B.; Hitaj, C. Growing organic demand provides high-value opportunities for many types of producers. In Amber Waves; United States Department of Agriculture Economic Research Service: Washington, DC, USA, 2017. Available online: https:/ /www.ers.usda.gov/amber-waves/2017/januaryfebruary/growing-organic-demand-provideshigh-value-opportunities-for-many-types-of-producers / (accessed on 27 January 2021).

2. Narayan, R.; Narayan, S. Precision farming in vegetables. In Precision Farming: A New Approach; Ram, T., Lohan, S.K., Singh, R., Singh, P., Eds.; Daya Publishing House: Delhi, India, 2014; p. 383.

3. Izquierdo, J. Biotechnology can help crop production to feed an increasing world population-positive and negative aspects need to be balanced: A perspective from FAO. In Plant Genetic Engineering: Towards the Third Millennium, Proceedings of the International Symposium on Plant Genetic Engineering, Havana, Cuba, 6-8 May 2020; FAO Regional Office for Latin America and the Caribbean: Santiago, Chile, 2020; Volumes 6-10, pp. 13-26.

4. Grossnickle, S.C.; MacDonald, J.E. Why seedlings grow: Influence of plant attributes. New For. 2018, 49, 1-34. [CrossRef]

5. Minami, K. High quality of seedling in vegetable production. In Proceedings of the IX International Symposium on Timing of Field Production in Vegetable Crops, Piracicaba, Sao Paulo, Brazil, 20-24 May 2001.

6. Grossnickle, S.C. Importance of root growth in overcoming planting stress. New For. 2005, 30, 273-294. [CrossRef]

7. Grossnickle, S.C.; Kiiskila, S.B.; Haase, D.L. Seedling ecophysiology: Five questions to explore in the nursery for optimizing subsequent field success. Tree Plant Notes 2020, 63, 112-127.

8. Landis, T.D. Root culturing in bareroot nurseries. For. Nurs. Notes 2008, 30, 9-15.

9. Bayoumi, Y.A.; El-Henawy, A.S.; Abdelaal, K.A.A.; Elhawat, N. Grape fruit waste compost as a nursery substrate ingredient for high-quality cucumber (Cucumis sativus L.) seedlings production. Compost Sci. Util. 2019, 27, 205-216. [CrossRef]

10. Pascual, J.A.; Ceglie, F.; Tuzel, Y.; Koller, M.; Koren, A.; Hitchings, R.; Tittarelli, F. Organic substrate for transplant production in organic nurseries. A review. Agron. Sustain. Dev. 2018, 38, 35. [CrossRef]

11. Meng, X.; Dai, J.; Zhang, Y.; Wang, X.; Zhu, W.; Yuan, X.; Yuan, H.; Cui, Z. Composted biogas residue and spent mushroom substrate as a growth medium for tomato and pepper seedlings. J. Environ. Manag. 2018, 216, 62-69. [CrossRef]

12. Ronga, D.; Pane, C.; Zaccardelli, M.; Pecchioni, N. Use of spent coffee ground compost in peat-based growing media for the production of basil and tomato potting plants. Commun. Soil Sci. Plant. 2016, 47, 356-368. [CrossRef]

13. Stewart-Wade, S.M. Efficacy of organic amendments used in containerized plant production: Part 1-Compost-based amendments. Sci. Hortic. 2020, 266, 108856. [CrossRef]

14. Carmona, E.; Moreno, M.T.; Avilés, M.; Ordovás, J. Use of grape marc compost as substrate for vegetable seedlings. Sci. Hortic. 2012, 137, 69-74. [CrossRef]

15. Chrysargyris, A.; Stamatakis, A.; Moustakas, K.; Prasad, M.; Tzortzakis, N. Evaluation of municipal solid waste compost and/or fertigation as peat substituent for pepper seedlings production. Waste Biomass Valorization 2018, 9, 2285-2294. [CrossRef]

16. Owen, W.G.; Jackson, B.E.; Whipker, B.E.; Fonteno, W.C.; Benson, M.D. Assessing the severity of damping-off caused by Pythium ultimum and Rhizoctonia solani in peat-based greenhouse substrates amended with pine wood chip aggregates. Acta Hortic. 2019, 1266, 27-34. [CrossRef]

17. Kanaan, H.; Hadar, Y.; Medina, S.; Krasnovsky, A.; Mordechai-Lebiush, S.; Tsror, L. Effect of compost properties on progress rate of Verticillium dahliae attack on eggplant (Solanum melongena L.). Compost Sci. Util. 2018, 26, 71-78. [CrossRef]

18. Shi, L.; Du, N.; Yuan, Y.; Shu, S.; Sun, J.; Guo, S. Vinegar residue compost as a growth substrate enhances cucumber resistance against the Fusarium wilt pathogen Fusarium oxysporum by regulating physiological and biochemical responses. Environ. Sci. Pollut. Res. 2016, 23, 18277-18287. [CrossRef] [PubMed]

19. Morales, A.B.; Ros, M.; Ayuso, L.M.; Bustamante, M.; de Los, A.; Moral, R.; Pascual, J.A. Agroindustrial composts to reduce the use of peat and fungicides in the cultivation of muskmelon seedlings. J. Sci. Food Agric. 2017, 97, 875-881. [CrossRef]

20. Pane, C.; Piccolo, A.; Spaccini, R.; Celano, G.; Villecco, D.; Zaccardelli, M. Agricultural waste-based composts exhibiting suppressivity to diseases caused by the phytopathogenic soil-borne fungi Rhizoctonia solani and Sclerotinia minor. Appl. Soil Ecol. 2013, 65, 43-51. [CrossRef]

21. Diab, H.G.; Hu, S.; Benson, D.M. Suppression of Rhizoctonia solani on impatiens by enhanced microbial activity in composted swine waste-amended potting mixes. Phytopathology 2003, 93, 1115-1123. [CrossRef] [PubMed]

22. Pane, C.; Spaccini, R.; Piccolo, A.; Scala, F.; Bonanomi, G. Compost amendments enhance peat suppressiveness to Pythium ultimum, Rhizoctonia solani and Sclerotinia minor. Biol. Control 2011, 56, 115-124. [CrossRef]

23. Segarra, G.; Santpere, G.; Elena, G.; Trillas, I. Enhanced Botrytis cinerea resistance of Arabidopsis plants grown in compost may be explained by increased expression of defense-related genes, as revealed by microarray analysis. PLoS ONE 2013, 8, e56075. [CrossRef] 
24. Blaya, J.; Lloret, E.; Ros, M.; Pascual, J.A. Identification of predictor parameters to determine agro-industrial compost suppressiveness against Fusarium oxysporum and Phytophthora capsici diseases in muskmelon and pepper seedlings. J. Sci. Food Agric. 2015, 95, 1482-1490. [CrossRef]

25. Pane, C.; Sorrentino, R.; Scotti, R.; Molisso, M.; Di Matteo, A.; Celano, G.; Zaccardelli, M. Alpha and beta-diversity of microbial communities associated to plant disease suppressive functions of on-farm green composts. Agriculture 2020, 10, 113. [CrossRef]

26. Scotti, R.; Mitchell, A.L.; Pane, C.; Finn, R.D.; Zaccardelli, M. Microbiota characterization of agricultural green waste-based suppressive composts using omics and classic approaches. Agriculture 2020, 10, 61. [CrossRef]

27. De Corato, U.; Salimbeni, R.; De Pretis, A. Suppression of soil-borne pathogens in container media amended with on-farm composted agro-bioenergy wastes and residues under glasshouse condition. J. Plant Dis. Prot. 2018, 125, 213-226. [CrossRef]

28. Pascual, J.A.; Bernal-Vicente, A.; Martinez-Medina, A.; Ros, M.; Sánchez, C. Biostimulant and suppressive effect of Trichoderma harzianum enriched compost for melon cultivation from greenhouse nursery to field production. Acta Hortic. 2017, 1164, 225-232. [CrossRef]

29. Oka, Y.; Yermiyahu, U. Suppressive effects of composts against the root-knot nematode Meloidogyne javanica on tomato. Nematology 2002, 4, 891-898. [CrossRef]

30. Pane, C.; Spaccini, R.; Piccolo, A.; Celano, G.; Zaccardelli, M. Disease suppressiveness of agricultural greenwaste composts as related to chemical and bio-based properties shaped by different on-farm composting methods. Biol. Control 2019, 137, 104026. [CrossRef]

31. Markakis, E.A.; Fountoulakis, M.S.; Daskalakis, G.C.; Kokkinis, M.; Ligoxigakis, E.K. The suppressive effect of compost amendments on Fusarium oxysporum f. sp. radicis-cucumerinum in cucumber and Verticillium dahliae in eggplant. Crop Prot. 2016, $79,70-79$.

32. Abouelenien, F.; Fujiwara, W.; Namba, Y.; Kosseva, M.; Nishio, N.; Nakashimada, Y. Improved methane fermentation of chicken manure via ammonia removal by biogas recycle. Bioresour. Technol. 2010, 101, 6368-6373. [CrossRef] [PubMed]

33. Nie, H.; Jacobi, H.F.; Strach, K.; Xu, C.; Zhou, H.; Liebetrau, J. Mono-fermentation of chicken manure: Ammonia inhibition and recirculation of the digestate. Bioresour. Technol. 2015, 178, 238-246. [CrossRef]

34. Bortolini, S.; Macavei, L.I.; Saadoun, J.H.; Foca, G.; Ulrici, A.; Bernini, F.; Malferrari, D.; Setti, L.; Ronga, D.; Maistrello, L. Hermetia illucens (L.) larvae as chicken manure management tool for circular economy. J. Clean. Prod. 2020, 262, 121289. [CrossRef]

35. Setti, L.; Francia, E.; Pulvirenti, A.; Gigliano, S.; Zaccardelli, M.; Pane, C.; Caradonia, F.; Bortolini, S.; Maistrello, L.; Ronga, D. Use of black soldier fly (Hermetia illucens (L.), Diptera: Stratiomyidae) larvae processing residue in peat-based growing media. Waste Manag. 2019, 95, 278-288. [CrossRef]

36. Ronga, D.; Mantovi, P.; Pacchioli, M.T.; Pulvirenti, A.; Bigi, F.; Allesina, G.; Pedrazzi, S.; Dal Prà, A. Combined effects of dewatering, composting and pelleting to valorize and delocalize livestock manure, improving agricultural sustainability. Agronomy 2020, 10, 661. [CrossRef]

37. Pane, C.; Celano, G.; Villecco, D.; Zaccardelli, M. Control of Botrytis cinerea, Alternaria alternata and Pyrenochaeta lycopersici on tomato with whey compost-tea application. Crop Prot. 2012, 38, 80-86. [CrossRef]

38. Lanthier, M. Compost tea and its impact on plant diseases. BC Org. Grow. 2007, 10, 7-11.

39. Scheuerell, S.J.; Mahaffee, W.F. Compost tea: Principles and prospect for plant disease control. Compost Sci. Util. 2002, 10, 313-338. [CrossRef]

40. Ingham, E.R. What is compost tea? Part 1. BioCycle 1999, 40, 74-75.

41. Mengesha, W.K.; Powel, S.M.; Evans, K.J.; Barry, K.M. Diverse microbial communities in non-aerated compost teas suppress bacterial wilt. World J. Microbiol. Biotechnol. 2017, 33, 49. [CrossRef]

42. Pane, C.; Celano, G.; Zaccardelli, M. Metabolic patterns of bacterial communities in aerobic compost teas associated with potential biocontrol of soilborne plant diseases. Phytopathol. Mediterr. 2014, 53, 277-286.

43. Pane, C.; Palese, A.M.; Celano, G.; Zaccardelli, M. Effects of compost tea treatments on productivity of lettuce and kohlrabi systems under organic cropping management. Ital. J. Agron. 2014, 9, 596. [CrossRef]

44. Pane, C.; Palese, A.M.; Spaccini, R.; Piccolo, A.; Celano, G.; Zaccardelli, M. Enhancing sustainability of a processing tomato cultivation system by using bioactive compost teas. Sci. Hortic. 2016, 202, 117-124. [CrossRef]

45. Scheuerell, S.J.; Mahaffee, W.F. Compost tea as a container medium drench for suppressing seedling damping-off by Pythium ultimum. Phytopathology 2004, 94, 1156-1163. [CrossRef] [PubMed]

46. Al-Mughrabi, K.I.; Berthélémé, C.; Livingston, T.; Burgoyne, A.; Poirier, R.; Vikram, A. Aerobic compost tea, compost and a combination of both reduce the severity of common scab (Streptomyces scabiei) on potato tubers. J. Plant Sci. 2008, 3, 168-175. [CrossRef]

47. El-Masry, M.H.; Khalil, A.I.; Hassouna, M.S.; Ibrahim, H.A.H. In situ and in vitro suppressive effect of agricultural composts and their water extracts on some phytopathogenic fungi. World J. Microbiol. Biotechnol. 2002, 18, 551-558. [CrossRef]

48. Zhang, W.; Han, D.J.; Dick, W.A.; Davis, K.R.; Hoitink, H.A.J. Compost and compost water extract-Induced systemic acquired in cucumber and Arabidopsis. Phytopathology 1998, 88, 450-545. [CrossRef] [PubMed]

49. Koné, S.B.; Dionne, A.; Tweddel, R.J.; Antoun, H.; Avis, T.J. Suppressive effect of non-aerated compost teas on foliar fungal pathogens of tomato. Biol. Control 2010, 52, 167-173. [CrossRef]

50. Al-Dahmani, J.H.; Abbassi, P.A.; Miller, S.A.; Hoitink, H.A.J. Suppression of bacterial spot of tomato with foliar sprays of compost extracts under greenhouse and field conditions. Plant Dis. 2003, 87, 913-919. [CrossRef] 
51. Edwards, C.A.; Arancon, N.Q.; Greytak, S. Effects of vermicompost teas on plant growth and disease. Biocycle 2006, 47, $28-31$.

52. Elad, Y.; Shtienberg, D. Effect of compost water extracts on grey mould (Botrytis cinerea). Crop Prot. 1994, 13, 109-114. [CrossRef]

53. Liguori, L.; Pane, C.; Albanese, D.; Celano, G.; Zaccardelli, M.; Di Matteo, M. Compost and compost tea management of mini watermelon cultivations affect the chemical, physical and sensory assessment of the fruits. Agric. Sci. 2015, 6, 117-125. [CrossRef]

54. Pant, A.; Radovich, T.J.K.; Hue, N.V.; Talcott, S.T.; Krenek, K.A. Vermicompost extracts influence growth, mineral nutrients, phytonutrients and antioxidant activity in Pak choi (Brassica rapa cv. Bonsai Chinensis group) grown under vermicompost and chemical fertilizer. J. Sci. Food Agric. 2009, 89, 2383-2392. [CrossRef]

55. Pant, A.; Radovich, T.J.K.; Hue, N.V.; Arancon, N.Q. Effects of vermicompost tea (aqueous extract) on pak-choi yield, quality, and on soil biological properties. Compost Sci. Util. 2011, 19, 279-292. [CrossRef]

56. Ronga, D.; Caradonia, F.; Setti, L.; Hagassou, D.; Giaretta Azevedo, C.V.; Milc, J.; Pedrazzi, S.; Allesina, G.; Arru, L.; Francia, E. Effects of innovative biofertilisers on yield of processing tomato cultivated in organic cropping systems in northern Italy. Acta Hortic. 2019, 1233, 129-136. [CrossRef]

57. Welke, S.E. The effect of compost extract on the yield of strawberries and the severity of Botrytis cinerea. J. Sustain. Agric. 2005, 25, 57-68. [CrossRef]

58. Zaccardelli, M.; Pane, C.; Villecco, D.; Palese, A.M.; Celano, G. Compost tea spraying increases yield performance of pepper (Capsicum annuum L.) grown in greenhouse under organic farming system. Ital. J. Agron. 2018, 13, 229-234. [CrossRef]

59. Bernal-Vincente, A.; Ros, M.; Tittarelli, F.; Intrigliolo, F.; Pascual, J.A. Citrus compost and its water extract for cultivation of melon plants in green house nurseries. Evaluation of nutriactive and biocontrol effects. Bioresour. Technol. 2008, 99, 8722-8728. [CrossRef]

60. Siddiqui, Y.; Sariah, M.; Razi, I.; Mawardi, R.; Asgar, A. Bio-efficiency of compost extracts on the wet rot incidence, morphological and physiological growth of okra (Abelmoschus esculentus [(L.) Moench]). Sci. Hortic. 2008, 117, 9-14. [CrossRef]

61. Siddiqui, Y.; Sariah, M.; Razi, I.; Mawardi, R. Bio-potential of compost tea from agro-waste to suppress Choanephora cucurbitarum L. the causal pathogen of wet rok of okra. Biol. Control 2009, 49, 38-44. [CrossRef]

62. Ekabote, S.D.; Divyajyothi, U.; Narayanaswamy, P.; Ravindra, H. Evaluation of propamocarb $530+$ fosetyl 310-840 SL for the management of damping off of vegetables. J. Pharmacogn. Phytochem. 2019, 8, 1616-1618.

63. Gilardi, G.; Demarchi, S.; Gullino, M.L.; Garibaldi, A. Nursery treatments with non-conventional products against crown and root rot, caused by Phytophthora capsici, on zucchini. Phytoparasitica 2015, 43, 501-508. [CrossRef]

64. Villecco, D.; Pane, C.; Ronga, D.; Zaccardelli, M. Enhancing sustainability of tomato, pepper and melon nursery production systems by using compost tea spray applications. Agronomy 2020, 10, 1336. [CrossRef]

65. Guo, Z.; Han, J.; Li, J.; Xu, Y.; Wang, X. Effects of long-term fertilization on soil organic carbon mineralization and microbial community structure. PLOS ONE 2019, 14, e0211163.

66. Chen, J.; Lü, S.; Zhang, Z.; Zhao, X.; Li, X.; Ning, P.; Liu, M. Environmentally friendly fertilizers: A review of materials used and their effects on the environment. Sci. Total Environ. 2018, 613-614, 829-839. [CrossRef] [PubMed]

67. European Commission. Communication from The Commission to the European Parliament, The Council, The European Economic and Social Committee and The Committee of the Regions Closing the Loop-An EU Action Plan for the Circular Economy. 2015. Available online: https:// eur-lex.europa.eu/legal-content/EN/TXT/?uri=CELEX\%3A52015DC0614 (accessed on 21 January 2021).

68. European Commission. A Sustainable Bioeconomy for Europe: Strengthening the Connection between Economy, Society and the Environment. Updated Bioeconomy Strategy. 2018. Available online: https:/ / op.europa.eu:443/en/publication-detail/-/ publication/edace3e3-e189-11e8-b690-01aa75ed71a1/language-en (accessed on 21 January 2021).

69. Regulation (EU) 2019/1009 of the European Parliament and of the Council of 5 June 2019 Laying Down Rules on the Making Available on the Market of EU Fertilising Products and Amending Regulations (EC) No 1069/2009 and (EC) No 1107/2009 and Repealing Regulation (EC) No 2003/2003) Regulations. Available online: https:/ / eur-lex.europa.eu/eli/reg/2019/1009/oj (accessed on 21 January 2021).

70. Abbasi, T.; Tauseef, S.M.; Abbasi, S.A. Anaerobic digestion for global warming control and energy generation-An overview. Renew. Sustain. Energy Rev. 2012, 16, 3228-3242. [CrossRef]

71. Monnet, F. An Introduction to Anaerobic Digestion of Organic Wastes. A Report. Remade Scotland. 2003. Available online: https: / / www.cti2000.it/Bionett/BioG-2003-002\%20IntroAnaerobicDigestion.pdf (accessed on 27 January 2021).

72. Nkoa, R. Agricultural benefits and environmental risks of soil fertilization with anaerobic digestates: A review. Agron. Sustain. Dev. 2014, 34, 473-492. [CrossRef]

73. Aso, S.N. Digestate: The Coproduct of Biofuel Production in a Circular Economy, and New Results for Cassava Peeling Residue Digestate; Intech Open: London, UK, 2020; Available online: https://www.intechopen.com/online-first/digestate-the-coproduct-ofbiofuel-production-in-a-circular-economy-and-new-results-for-cassava-peel (accessed on 27 January 2021).

74. Jorobekova, S.; Kydralieva, K. Plant growth biostimulants from byproducts of anaerobic digestion of organic substances. In Organic Fertilizers—History, Production and Application; Larramendy, M., Solonesli, S., Eds.; Intech Open: London, UK, 2019; Available online: https://www.intechopen.com/books/organic-fertilizers-history-production-and-applications/plant-growthbiostimulants-from-by-products-of-anaerobic-digestion-of-organic-substances (accessed on 27 January 2021).

75. Yagüe, M.R.; Lobo, M.C. Liquid digestate from organic residues as fertilizer: Carbon fractions, phytotoxicity and microbiological analysis. SJSS 2020, 10, 248-256. 
76. Lencioni, G.; Imperiale, D.; Cavirani, N.; Marmiroli, N.; Marmiroli, M. Environmental application and phytotoxicity of anaerobic digestate from pig farming by in vitro and in vivo trials. Int. J. Environ. Sci. Technol. 2016, 13, 2549-2560. [CrossRef]

77. Ronga, D.; Setti, L.; Salvarani, C.; De Leo, R.; Bedin, E.; Pulvirenti, A.; Milc, J.; Pecchioni, N.; Francia, E. Effects of solid and liquid digestate for hydroponic baby leaf lettuce (Lactuca sativa L.) cultivation. Sci. Hortic. 2019, 244, 172-181. [CrossRef]

78. Ronga, D.; Pellati, F.; Brighenti, V.; Laudicella, K.; Laviano, L.; Fedailaine, M.; Benvenuti, S.; Pecchioni, N.; Francia, E. Testing the influence of digestate from biogas on growth and volatile compounds of basil (Ocimum basilicum L.) and peppermint (Mentha $x$ piperita L.) in hydroponics. J. Appl. Res. Med. Aroma 2018, 11, 18-26. [CrossRef]

79. Greco, C.; Comparetti, A.; Fascella, G.; Febo, P.; La Placa, G.; Saiano, F.; Mammano, M.M.; Orlando, S.; Laudicina, V.A. Effects of vermicompost, compost and digestate as commercial alternative peat-based substrates on qualitative parameters of Salvia officinalis. Agronomy 2021, 11, 98. [CrossRef]

80. Zeng, Y.; De Guardia, A.; Dabert, P. Improving composting as a post-treatment of anaerobic digestate. Bioresour. Technol. 2016, 201, 293-303. [CrossRef]

81. Vitti, A.; Elshafie, H.S.; Logozzo, G.; Marzario, S.; Scopa, A.; Camele, I.; Nuzzaci, M. Physico-chemical characterization and biological activities of a digestate and a more stabilized digestate-derived compost from agro-waste. Plants 2021, 10, 386. [CrossRef]

82. Ahuja, I.; Dauksas, E.; Remme, J.F.; Richardsen, R.; Løes, A.-K. Fish and fish waste-based fertilizers in organic farming-With status in Norway: A review. Waste Manag. 2020, 115, 95-112. [CrossRef]

83. Busato, J.G.; de Carvalho, C.M.; Zandonadi, D.B.; Sodré, F.F.; Mol, A.R.; de Oliveira, A.L.; Navarro, R.D. Recycling of wastes from fish beneficiation by composting: Chemical characteristics of the compost and efficiency of their humic acids instimulating the growth of lettuce. Environ. Sci. Pollut. Res. 2018, 25, 35811-35820. [CrossRef] [PubMed]

84. Billa, S.F.; Angwafo, T.E.; Ngome, A.F. Agro-environmental characterization of biochar issued from crop wastes in the humid forest zone of Cameroon. Int. J. Recycl. 2019, 8, 1-13. [CrossRef]

85. Monterumici, C.; Rosso, D.; Montoneri, E.; Ginepro, M.; Baglieri, A.; Novotny, E.E.; Kwapinski, W.; Negre, M. Processed vs non-processed biowastes for agriculture: Effects of post-harvest tomato plants and biochar on radish growth, chlorophyll content and protein production. Int. J. Mol. Sci. 2015, 16, 8826-8843. [CrossRef] [PubMed]

86. Kalus, K.; Koziel, J.A.; Opaliński, S. A review of biochar properties and their utilization in crop agriculture and livestock production. Appl. Sci. 2019, 9, 3494. [CrossRef]

87. Kaudal, B.B.; Chen, D.; Madhavan, D.B.; Downie, A.; Weatherley, A. An examination of physical and chemical properties of urban biochar for use as growing media substrate. Biomass Bioenergy 2016, 84, 49-58. [CrossRef]

88. Kaur, T. Vermicomposting: An effective option for recycling organic wastes. In Organic Agriculture; Das, S.K., Ed.; IntechOpen: London, UK, 2020; p. 17. Available online: https://www.intechopen.com/books/organic-agriculture/vermicomposting-aneffective-option-for-recycling-organic-wastes (accessed on 27 January 2021).

89. Atiyeh, R.M.; Subler, S.; Edwards, C.A.; Bachman, G.; Metzger, J.D. Effects of vermicomposts and composts on plant growth in horticultural container media and soil. Pedobiologia 2000, 44, 579-590. [CrossRef]

90. Andreola, F.; Borghi, A.; Pedrazzi, S.; Allesina, G.; Tartarini, P.; Lancellotti, I.; Barbieri, L. Spent coffee grounds in the production of lightweight clay ceramic aggregates in view of urban and agricultural sustainable development. Materials 2019, $12,3581$. [CrossRef] [PubMed]

91. Ronga, D.; Parisi, M.; Barbieri, L.; Lancellotti, I.; Andreola, F.; Bignami, C. Valorization of spent coffee grounds, biochar and other residues to produce lightweight clay ceramic aggregates suitable for nursery grapevine production. Horticulturae 2020, 6, 58 . [CrossRef]

92. Coppens, J.; Grunert, O.; Van Den Hende, S.; Vanhoutte, I.; Boon, N.; Haesaert, G.; De Gelder, L. The use of microalgae as a high-value organic slow-release fertiliser results in tomatoes with increased carotenoid and sugar levels. J. Appl. Phycol. 2016, 28, 2367-2377. [CrossRef]

93. Ronga, D.; Biazzi, E.; Parati, K.; Carminati, D.; Carminati, E.; Tava, A. Microalgal biostimulants and biofertilisers in crop productions. Agronomy 2019, 9, 192. [CrossRef]

94. Faheed, F.A.; Fattah, Z.A. Effect of Chlorella vulgaris as biofertiliser on growth parameters and metabolic aspects of lettuce plant. J. Agric. Soc. Sci. 2008, 4, 165-169.

95. Lv, J.; Liu, S.; Feng, J.; Liu, Q.; Guo, J.; Wang, L.; Xiaoyan, J.; Xie, S. Effects of microalgal biomass as biofertilizer on the growth of cucumber and microbial communities in the cucumber rhizosphere. Turk. J. Bot. 2020, 44, 167-177.

96. Bumandalai, O.; Tserennadmid, R. Effect of Chlorella vulgaris as a biofertilizer on germination of tomato and cucumber seeds. Int. J. Aquat. Biol. 2019, 7, 95-99.

97. Ciavatta, C.; Govi, M.; Sitti, L.; Gessa, C. Influence of blood meal organic fertilizer on soil organic matter: A laboratory study. J. Plant Nutr. 1997, 20, 1573-1591. [CrossRef]

98. Bae, E.J.; Kim, B.W.; Kim, M.J.; Kwon, S.H.; Choi, J.H.; Na, H. Growth response of some vegetables seedlings according to blood fertilizer. J. Korean Soc. People Plant Environ. 2015, 18, 47-52. [CrossRef]

99. Rouphael, Y.; Spíchal, L.; Panzarová, K.; Casa, R.; Colla, G. High-throughput plant phenotyping for developing novel biostimulants: From lab to field or from field to lab? Front. Plant Sci. 2018, 9, 1197. [CrossRef] 
100. Rouphael, Y.; Lucini, L.; Miras-Moreno, B.; Colla, G.; Bonini, P.; Cardarelli, M. Metabolomic responses of maize shoots and roots elicited by combinatorial seed treatments with microbial and non-microbial biostimulants. Front. Microbiol. 2020, 11, 664. [CrossRef] [PubMed]

101. Rouphael, Y.; Carillo, P.; Colla, G.; Fiorentino, N.; Sabatino, L.; El-Nakhel, C.; Giordano, M.; Pannico, A.; Cirillo, V.; Shabani, E.; et al. Appraisal of combined applications of Trichoderma virens and a biopolymer-based biostimulant on lettuce agronomical, physiological, and qualitative properties under variable $\mathrm{N}$ regimes. Agronomy 2020, 10, 196. [CrossRef]

102. Rouphael, Y.; Kyriacou, M.C.; Petropoulos, S.A.; De Pascale, S.; Colla, G. Improving vegetable quality in controlled environments. Sci. Hortic. 2018, 234, 275-289. [CrossRef]

103. Rouphael, Y.; Colla, G. Synergistic biostimulatory action: Designing the next generation of plant biostimulants for sustainable agriculture. Front. Plant Sci. 2018, 9, 1655. [CrossRef]

104. Goswami, M.; Deka, S. Plant growth-promoting rhizobacteria alleviators of abiotic stresses in soil-A review. Pedosphere 2020, 30, 40-61. [CrossRef]

105. Woo, S.L.; Pepe, O. Microbial Consortia: Promising probiotics as plant biostimulants for sustainable agriculture. Front. Plant Sci. 2018, 9, 1801. [CrossRef]

106. Caradonia, F.; Ronga, D.; Flore, A.; Barbieri, R.; Moulin, L.; Terzi, V.; Francia, E. Biostimulants and cherry rootstock increased tomato fruit yield and quality in sustainable farming systems. Ital. J. Agron. 2020, 15, 1553.

107. Bonini, P.; Cirino, V.; Reynaud, H.; Rouphael, Y.; Cardarelli, M.; Colla, G. Part 3: Innovation and practical applications-Designing and formulating microbial and non-microbial biostimulants. In Biostimulants for Sustainable Crop Production; Rouphael, Y., du Jardin, P., Brown, P., De Pascale, S., Colla, G., Eds.; Burleigh Dodds Science Publishing: Sawston, UK, 2019.

108. Cardarelli, M.; Rouphael, Y.; Coppa, E.; Hoagland, L.; Colla, G. Using microgranular-based biostimulant in vegetable transplant production to enhance growth and nitrogen uptake. Agronomy 2020, 10, 842. [CrossRef]

109. Ren, L.; Wang, B.; Yue, C.; Zhou, S.; Zhang, S.; Huo, H.; Xu, G. Mechanism of application nursery cultivation arbuscular mycorrhizal seedling in watermelon in the field. Ann. Appl. Biol. 2019, 174, 51-60. [CrossRef]

110. Bettoni, M.M.; Mogor, A.F.; Pauletti, V.; Goicoechea, N. Growth and metabolism of onion seedlings as affected by the application of humic substances, mycorrhizal inoculation and elevated $\mathrm{CO}_{2}$. Sci. Hortic. 2014, 180, 227-235. [CrossRef]

111. Mohamed, H.A.; Barry, K.M.; Measham, P.F. The role of arbuscular mycorrhizal fungi in establishment and water balance of tomato seedlings and sweet cherry cuttings in low phosphorous soil. Acta Hortic. 2016, 1112, 109-115. [CrossRef]

112. Ortas, I.; Sari, N.; Akpinar, C.; Yetsir, H. Screening mycorrhizae species for increased growth and P and Zn uptake in eggplant (Solanum melongena L.) grown under greenhouse conditions. Eur. J. Hortic. Sci. 2011, 76, 116-123.

113. Sensoy, S.; Ocak, E.; Demir, S.; Tufenkci, S. Effects of humic acid, whey and arbuscular mycorrhizal fungi (AMF) applications on seedling growth and Fusarium wilt in Zucchini (Cucurbita pepo L.). J. Anim. Plant Sci. 2013, 23, 507-513.

114. Ronga, D.; Caradonia, F.; Francia, E.; Morcia, C.; Rizza, F.; Badeck, F.R.; Ghizzoni, R.; Terzi, V. Interaction of tomato genotypes and arbuscular mycorrhizal fungi under reduced irrigation. Horticulturae 2019, 5, 79. [CrossRef]

115. Liu, A.; Chen, S.; Wang, M.; Liu, D.; Chang, R.; Wang, Z.; Lin, X.; Bai, B.; Ahammed, G.J. Arbuscular mycorrhizal fungus alleviates chilling stress by boosting redox poise and antioxidant potential of tomato seedlings. J. Plant Growth Regul. 2016, 35, 109-120. [CrossRef]

116. Caradonia, F.; Francia, E.; Morcia, C.; Ghizzoni, R.; Moulin, L.; Terzi, V.; Ronga, D. Arbuscular mycorrhizal fungi and plant growth promoting rhizobacteria avoid processing tomato leaf damage during chilling stress. Agronomy 2019, 9, 299. [CrossRef]

117. Bidabadi, S.S.; Mehralian, M. Arbuscular mycorrhizal fungi inoculation to enhance chilling stress tolerance of watermelon. Gesunde Pflanz. 2020, 72, 171-179. [CrossRef]

118. Turkmen, O.; Sensoy, S.; Demir, S.; Erdinc, C. Effects of two different AMF species on growth and nutrient content of pepper seedlings grown under moderate salt stress. Afr. J. Biotechnol. 2008, 7, 392-396.

119. Ge, H.; Zhonghua, L. Characteristics of Azotobacter sp. strain AC11 and their effects on the growth of tomato seedlings under salt stress. Emir. J. Food Agric. 2019, 31, 520-525. [CrossRef]

120. Mangmang, J.S.; Deaker, R.; Rogers, G. Early seedling growth response of lettuce, tomato and cucumber to Azospirillum brasilense inoculated by soaking and drenching. Hortic. Sci. 2015, 42, 37-46. [CrossRef]

121. Fasciglione, G.; Casanovas, E.M.; Yommi, A.; Sueldo, R.J.; Barassi, C.A. Azospirillum improves lettuce growth and transplant under saline conditions. Sci. Food Agric. 2012, 92, 2518-2523. [CrossRef]

122. Cortés-Jiménez, D.; Gómez-Guzmán, A.; Iturriaga, G.; Suárez, R.; Alpírez, G.M.; Escalante, F.M.E. Microorganisms associated to tomato seedlings growing in saline culture act as osmoprotectant. Braz. J. Microbiol. 2014, 45, 613-620. [CrossRef]

123. Noel, T.C.; Sheng, C.; Yost, C.K.; Pharis, R.P.; Hynes, M.F. Rhizobium leguminosarum as a plant growth-promoting rhizobacterium: Direct growth promotion of canola and lettuce. Can. J. Microbiol. 1996, 42, 279-283. [CrossRef]

124. Ferreira, L.D.V.M.; de Carvalho, F.; Andrade, J.F.C.; Oliveira, D.P.; De Medeiros, F.H.V.; Moreira, F.M.D.S. Co-inoculation of selected nodule endophytic rhizobacterial strains with Rhizobium tropici promotes plant growth and controls damping off in common bean. Pedosphere 2020, 30, 98-108. [CrossRef]

125. Piccolo, A.; Celano, G.; Pietramellara, G. Effects of fractions of coal-derived humic substances on seed germination and growth of seedlings (Lactuga sativa and Lycopersicum esculentum). Biol. Fert. Soils 1993, 16, 11-15. [CrossRef]

126. Lulakis, M.D.; Petsas, S.I. Effect of humic substances from vine-canes mature compost on tomato seedling growth. Bioresour. Technol. 1995, 54, 179-182. [CrossRef] 
127. Young, C.C.; Chen, L.F. Polyamines in humic acid and their effect on radical growth of lettuce seedlings. Plant Soil 1997, 195, 143-149. [CrossRef]

128. Hartwigsen, J.A.; Evans, M.R. Humic acid seed and substrate treatments promote seedling root development. HortScience 2000, 35, 1231-1233. [CrossRef]

129. Dursun, A.; Guvenx, I.; Turan, M. Effects of different levels of humic acids on seedling growth and macro and micronutrient contents of of tomato and eggplant. Acta Bot. 2002, 56, 81-88. [CrossRef]

130. Qin, K.; Leskovar, D.I. Humic substances improve vegetable seedling quality and post-transplant yield performance under stress conditions. Agriculture 2020, 10, 254. [CrossRef]

131. Mattner, S.W.; Wite, D.; Riches, D.A.; Porter, I.J.; Arioli, T. The effect of kelp extract on seedling establishment of broccoli on contrasting soil types in southern Victoria, Australia. Biol. Agric. Hortic. 2013, 29, 258-270. [CrossRef]

132. Hernández-Herrera, R.M.; Santacruz-Ruvalcaba, F.; Ruiz-López, M.A.; Norrie, J.; Hernández-Carmona, G. Effect of liquid seaweed extracts on growth of tomato seedlings (Solanum lycopersicum L.). J. Appl. Phycol. 2014, 26, 619-628. [CrossRef]

133. Puglisi, I.; La Bella, E.; Rovetto, E.I.; Lo Piero, L.A.; Baglieri, A. Biostimulant effect and biochemical response in lettuce seedlings treated with a Scenedesmus quadricauda extract. Plants 2020, 9, 123. [CrossRef] [PubMed]

134. De Pascale, S.; Rouphael, Y.; Colla, G. Plant biostimulants: Innovative tool for enhancing plant nutrition in organic farming. Eur. J. Hortic. Sci. 2017, 82, 277-285. [CrossRef]

135. Lucini, L.; Rouphael, Y.; Cardarelli, M.; Bonini, P.; Baffi, C.; Colla, G. A vegetal biopolymer-based biostimulant promoted root growth in melon while triggering brassinosteroids and stress-related compounds. Front. Plant Sci. 2018, 9, 472. [CrossRef] [PubMed]

136. Kim, H.J.; Ku, K.M.; Choi, S.; Cardarelli, M. Vegetal-derived biostimulant enhances adventitious rooting in cuttings of basil, tomato, and Chrysanthemum via brassinosteroid-mediated processes. Agronomy 2019, 9, 74. [CrossRef]

137. Colman, S.L.; Salcedo, M.F.; Mansilla, A.Y.; Iglesias, M.J.; Fiol, D.F.; Martin-Saldana, S.; Alvarez, V.A.; Chevalier, A.A.; Casalongué, C.A. Chitosan microparticles improve tomato seedling biomass and modulate hormonal, redox and defense pathways. Plant Physiol. Biochem. 2019, 143, 203-211. [CrossRef] [PubMed]

138. Bu, R.; Xie, J.; Yu, J.; Liao, W.; Xiao, X.; Lv, J.; Wang, C.; Ye, J.; Calderón-Urrea, A. Autotoxicity in cucumber (Cucumis sativus L.) seedlings is alleviated by silicon through an increase in the activity of antioxidant enzymes and by mitigating lipid peroxidation. J. Plant Biol. 2016, 59, 247-259. [CrossRef]

139. Aleandri, M.P.; Chilosi, G.; Bruni, N.; Tomassini, A.; Vettraino, A.M.; Vannini, A. Use of nursery potting mixes amended with local Trichoderma strains with multiple complementary mechanisms to control soil-borne disease. Crop Prot. 2015, 67, 269-278. [CrossRef]

140. Jaiswal, A.K.; Graber, E.R.; Elad, Y.; Frenkel, O. Biochar as a management tool for soilborne diseases affecting early stage nursery seedling production. Crop Prot. 2019, 120, 34-42. [CrossRef]

141. Gilardi, G.; Gullino, M.L.; Garibaldi, A. Preventative treatments in nursery with different biocontrol agents and potassium phosphite salt to control Fusarium wilt agents of lettuce and rocket. Acta Hortic. 2020, 1270, 295-300. [CrossRef]

142. González, V.; Armijos, E.; Garcés-Claver, A. Fungal endophytes as biocontrol agents against the main soil-borne diseases of melon and watermelon in Spain. Agronomy 2020, 10, 820. [CrossRef]

143. Tjosvold, S.A.; Chambers, D.L.; Koike, S.T.; Mori, S.R. Disease on nursery stock as affected by environmental factors and seasonal inoculum levels of Phytophthora ramorum in stream water used for irrigation. Plant Dis. 2008, 92, 1566-1573. [CrossRef]

144. Parke, J.L.; Grünwald, N.J. A systems approach for management of pests and pathogens of nursery crops. Plant Dis. 2012, 96, 1236-1244. [CrossRef] [PubMed]

145. Anith, K.N.; Radhakrishnan, N.V.; Manomohandas, T.P. Screening of antagonistic bacteria for biologicalcontrol of nursery wilt of black pepper (Piper nigrum L.). Microbiol. Res. 2003, 158, 91-97. [CrossRef] [PubMed]

146. Sun, D.; Zhuo, T.; Hu, X.; Fan, X.; Zou, H. Identification of a Pseudomonas putida as biocontrol agent for tomato bacterial wilt disease. Biol. Control 2017, 114, 45-50. [CrossRef]

147. O'Brien, P.A. Biological control of plant diseases. Australas. Plant Pathol. 2017, 46, 293-304. [CrossRef]

148. Verma, C.; Gupta, B.K.; Singh, A.; Kujur, A.; Sahu, R.; Prajapati, P. Biological control agents in the management of bell pepper nursery diseases: A review. J. Pharmacogn. Phytoch. 2020, 9, 462-468.

149. Pal, K.K.; McSpadden Gardener, B. Biological control of plant pathogens. Plant Health Instr. 2006, 1117-1202. [CrossRef]

150. Hermosa, R.; Viterbo, A.; Chet, I.; Monte, E. Plant-beneficial effects of Trichoderma and of its genes. Microbiology 2012, 158, 17-25. [CrossRef]

151. Lamichhane, J.R.; Dürr, C.; Schwanck, A.A.; Marie-Hélène, R.; Sarthou, J.P.; Cellier, V.; Messéan, A.; Aubertot, J.N. Integrated management of damping-off diseases. A review. Agron. Sustain. Dev. 2017, 37, 10. [CrossRef]

152. Woo, S.L.; Ruocco, M.; Vinale, F.; Nigro, M.; Marra, R.; Lombardi, N.; Pascale, A.; Lanzuise, S.; Manganiello, G.; Lorito, M. Trichoderma-based products and their widespread use in agriculture. Open Mycol. J. 2014, 8, 71-126. [CrossRef]

153. Tsahouridou, P.C.; Thanassoulopoulos, C.C. Proliferation of Trichoderma koningii in the tomato rhizosphere and the suppression of damping-off by Sclerotium rolfsii. Soil Biol. Biochem. 2002, 34, 767-776. [CrossRef]

154. Nayak, B.K. Isolation and identification of phylloplane and endophytic fungi from one ornamental plant, Mangifera indica. Int. J. Chemtech. Res. 2015, 1, 188-192. 
155. Hoitink, H.A.; Musselman, C.A.; Moore, T.L.; Horst, L.; Krause, C.R.; Zondag, R.A.; Mathers, H. Biological suppression of foliar diseases of ornamental plants with composted manures, biosolids, and Trichoderma hamatum 382. Ext. Circ. 2003, $189,50-56$.

156. Widmer, T.L.; Johnson-Brousseau, S.; Kosta, K.; Ghosh, S.; Schweigkofler, W.; Sharma, S.; Suslow, K. Remediation of Phytophthora ramorum-infested soil with Trichoderma asperellum isolate 04-22 under ornamental nursery conditions. Biol. Control 2018, 118, 67-73. [CrossRef]

157. Lo, C.-T.; Nelson, E.B.; Hayes, C.K.; Harman, G.E. Ecological studies of transformed Trichoderma harzianum strain $1295-22$ in the rhizosphere and on the phylloplane of creeping bentgrass. Phytopathology 1998, 88, 129-136. [CrossRef] [PubMed]

158. Cutler, H.G.; Himmelsbach, D.S.; Arrendale, R.F.; Cole, P.D.; Cox, R.H. Koninginin A: A novel plant growth regulator from Trichoderma koningii. Agr. Biol. Chem. 1989, 53, 2605-2611. [CrossRef]

159. Benítez, T.; Rincon, A.M.; Limon, M.C.; Codon, A.C. Biocontrol mechanisms of Trichoderma strains. Int. Microbiol. 2004, 7, 249-260. [PubMed]

160. Vitti, A.; Nuzzaci, M.; Scopa, A.; Sofo, A. Indirect and direct benefits of the use of Trichoderma harzianum strain T-22 in agronomic plants subjected to abiotic and biotic stresses. In Abiotic Stresses in Crop Plants; Chakraborty, U., Chakraborty, B., Eds.; CABI: Wallingford, UK, 2015; pp. 222-231.

161. Vitti, A.; Pellegrini, E.; Nali, C.; Lovelli, S.; Sofo, A.; Valerio, M.; Scopa, A.; Nuzzaci, M. Trichoderma harzianum T-22 induces systemic resistance in tomato infected by cucumber mosaic virus. Front. Plant Sci. 2016, 7, 1-11. [CrossRef] [PubMed]

162. Srivastava, J.N.; Singh, A.K.; Kumar, M.; Kumai, A.; Kumar, R. Management of damping-off disease of seedling caused in solanaceous and cruciferous vegetable through integrated approach. J. Pharmacogn. Phytoch. 2018, 1, 3000-3003.

163. Hewavitharana, N.; Kannangara, S.D.P. Evaluation of organic potting media enriched with Trichoderma spp. and their effect on growth performance of selected vegetables. Int. J. Sci. Basic Appl. 2019, 6, 13-25.

164. Nahar, N.; Islam, R.; Uddin, M.M.; de Jong, P.; Struik, P.C.; Stomph, T.J. Reducing damping-off problems in eggplant (Solanum melongena L.): A participatory testing of nursery management in Bangladesh. Crop Prot. 2018, 112, 177-186. [CrossRef]

165. Nahar, N.; Islam, R.; Uddin, M.M.; Jong, P.; Struik, P.C.; Stomph, T.J. Disease management in eggplant (Solanum melongena L.) nurseries also reduces wilt and fruit rot in subsequent plantings: A participatory testing in Bangladesh. Crop Prot. 2019, 120, 113-124. [CrossRef]

166. Mastouri, F.; Bjoerkman, T.; Harman, G.E. Seed treatment with Trichoderma harzianum alleviates biotic, abiotic, and physiological stresses in germinating seeds and seedlings. Phytopathology 2010, 100, 1213-1221. [CrossRef]

167. Martinez-Medina, A.; Pascual, J.A.; Lloret, E.; Roldan, A. Interactions between arbuscular mycorrhizal fungi and Trichoderma harzianum and their effects on Fusarium wilt in melon plants grown in seedling nurseries. J. Sci. Food Agric. 2009, 89, 1843-1850. [CrossRef]

168. de Vrije, T.; Antoine, N.; Buitelaar, R.; Bruckner, S.; Dissevelt, M.; Durand, A.; Gerlagh, M.; Jones, E.; Lüth, P.; Oostra, J.; et al. The fungal biocontrol agent Coniothyrium minitans: Production by solid-state fermentation, application and marketing. Appl. Microbiol. Biotechnol. 2001, 56, 58-68. [CrossRef]

169. Patil, S.; Sriram, S. Biological control of Fusarium wilt in crop plants using non-pathogenic isolates of Fusarium species. Indian Phytopathol. 2020, 73, 11-19. [CrossRef]

170. Punja, Z.K.; Utkhede, R.S. Using fungi and yeasts to manage vegetable crop diseases. Trends Biotechnol. 2003, $21,400-407$. [CrossRef]

171. Gerbore, J.; Benhamou, N.; Vallance, J.; Le Floch, G.; Grizard, D.; Regnault-Roger, C.; Rey, P. Biological control of plant pathogens: Advantages and limitations seen through the case study of Pythium oligandrum. Environ. Sci. Pollut. Res. 2014, 21, 4847-4860. [CrossRef] [PubMed]

172. Almoneafy, A.A.; Kakar, K.U.; Nawaz, Z.; Li, B.; Saand, M.A.; Chun-lan, Y.; Xie, G. Tomato plant growth promotion and antibacterial related-mechanisms of four Rhizobacterial bacillus strains against Ralstonia solanacearum. Symbiosis 2014, 63, 59-70. [CrossRef]

173. Baysal, O.; Çalişkan, M.; Yeşilova, O. An inhibitory effect of a new Bacillus subtilis strain (EU07) against Fusarium oxysporum f. sp. radicis-lycopersici. Physiol. Mol. Plant Path 2008, 73, 25-32. [CrossRef]

174. Buchenauer, H. Biological control of soil-borne diseases by rhizobacteria. J. Plant Dis. Prot. 1998, 105, $329-348$.

175. Heydari, A.; Pessarakli, M. A review on biological control of fungal plant pathogens using microbial antagonist. J. Biol. Sci. 2010, 10, 273-290. [CrossRef]

176. Ouhaibi-Ben, A.N.; Vallance, J.; Gerbore, J.; Rey, P.; Daami-Remadi, M. Bio-suppression of Sclerotinia stem rot of tomato and biostimulation of plant growth using tomato-associated rhizobacteria. J. Plant Pathol. Microbiol. 2016, 7, 1000331.

177. Weller, M. Biological control of soil borne plant pathogens in the rhizosphere with bacteria. Ann. Rev. Phytopathol. 1998, 26, 379-407. [CrossRef]

178. Asaka, O.; Shoda, M. Biocontrol of rhizoctonia solani damping-off of tomato with Bacillus subtilis RB14. Appl. Environ. Microbiol. 1996, 62, 4081-4085. [CrossRef] [PubMed]

179. Huang, X.; Zhang, N.; Yong, X.; Yang, X.; Shen, Q. Biocontrol of Rhizoctonia Solani damping-off disease in cucumber with Bacillus pumilus SQR-N43. Microbiol. Res. 2012, 167, 135-143. [CrossRef] [PubMed]

180. Kloepper, J.W.; Schroth, M.N.; Miller, T.D. Effects of rhizosphere colonizaton by plant growth-promoting rhizobacteria on potato plant development and yield. Phytopathology 1980, 70, 1078-1082. [CrossRef] 
181. Kloepper, J.W.; Lifshitz, R.; Zablotowicz, R.M. Free-living bacterial inocula for enhancing crop productivity. Tibthech 1989, 7, 39-44. [CrossRef]

182. Suslow, T.V.; Schroth, M.N. Rhizobacteria of sugar beets: Effects of seed application and root colonization on yield. Phytopathology 1982, 72, 199-206. [CrossRef]

183. Tang, W.H. Yield increasing bacteria (YIB) and biocontrol of sheath blight in rice. In Improving Plant Productivity with Rhizosphere Bacteria; Ryder, M.H., Stephens, P.M., Bowen, G.D., Eds.; CSIRO Division of Soils: Adelaide, Australia, 1994; pp. $267-273$.

184. Agrios, G.N. Plant Pathology; Academic Press: San Diego, CA, USA, 2005.

185. Bowers, J.H.; Park, J.L. Epidemiology of Pythium damping-off and Aphanomyces root-rot of peas after seed treatment with bacterial agents for biocontrol. Phytopathology 1993, 83, 1466-1473. [CrossRef]

186. Dimkic, I.; Zivkovic, S.; Beric, T.; Ivanovic, Z.; Gavrilovic, V.; Stankovic, S.; Fira, D. Characterization and evaluation of two Bacillus strains, SS-12.6 and SS-13.1, as potential agents for the control of phytopathogenic bacteria and fungi. Biol. Control 2013, 65, 312-321. [CrossRef]

187. Han, J.S.; Cheng, J.H.; Yoon, T.M.; Song, J.; Rajkarnikar, A.; Kim, W.G. Biological control agent of common scab disease by antagonistic strain Bacillus sp. sunhua. J. Appl. Microbiol. 2005, 99, 213-221. [CrossRef] [PubMed]

188. Khedher, S.B.; Kilani-Feki, O.; Dammak, M.; Jabnoun-Khiareddine, H.; Daami-Remadi, M.; Slim Tounsi, S. Efficacy of Bacillus subtilis V26 as a biological control agent against Rhizoctonia solani on potato. Comptes Rendus Biol. 2015, 338, 784-792. [CrossRef]

189. Leben, S.D.; Wadi, J.A.; Easton, G.D. Effects of Pseudomonas fluorescens on potato plant growth and control of Verticillium dahliae. Phytopathology 1987, 77, 1592-1595. [CrossRef]

190. Pane, C.; Villecco, D.; Campanile, F.; Zaccardelli, M. Novel strains of Bacillus, isolated from compost and compost-amended soils, as biological control agents against soil-borne phytopathogenic fungi. Biocontrol Sci. Technol. 2012, 22, 1373-1388. [CrossRef]

191. Pane, C.; Zaccardelli, M. Evaluation of Bacillus strains isolated from Solanaceous phylloplane for biocontrol of Alternaria early blight of tomato. Biol. Control 2015, 84, 11-18. [CrossRef]

192. Zaccardelli, M.; Sorrentino, R.; Caputo, M.; Scotti, R.; De Falco, E.; Pane, C. Stepwise-selected Bacillus amyloliquefaciens and B. subtilis strains from composted aromatic plant waste able to control soil-borne diseases. Agriculture 2020, 10, 30. [CrossRef]

193. Costaccurta, A.; Vanderleyden, B. Synthesis of phythormones by plant associated bacteria. Crit. Rev. Microbiol. 1995, 21, 1-18. [CrossRef]

194. D'Agostino, N.; Sorrentino, R.; Scotti, R.; Salzano, M.; Aurilia, V.; Zaccardelli, M. Draft genome sequence of the plant growthpromoting Rhizobacterium Pseudomonas fluorescens strain CREA C16 isolated from pea (Pisum sativum L.). Rhizosphere 2017, 5, e01456-e01516. [CrossRef] [PubMed]

195. Gutiérrez-Mañero, F.J.; Ramos-Solano, B.; Probanda, A.; Mehouachi, J.; Tadeo, F.R.; Talon, M. The plant growth-promoting rhizobacteria Bacillus pumilis and Bacillus licheniformis produce high amounts of physiologically active gibberellins. Physiol. Plant 2001, 111, 206-211. [CrossRef]

196. Kobayashi, M.; Suzuki, T.; Fruita, T.; Masuda, M.; Shinizu, S. Occurrence of enzymes ivolved in biosynthesis of indole-3-acetic acid from indole-3-acetonitrile in plant-associated bacteria, Agrobacteria and Rhizobium. Proc. Natl. Acad. Sci. USA 1995, 92, 714-718. [CrossRef]

197. Lopez, J.E.; Schroth, M.N. Influence of bacterial sources of indole-3-acetic on root elongation of sugar beet. Phytopathology 1986, 76, 386-389.

198. Cassan, F.; Diaz-Zorita, M. Azospirillum spp. in current agriculture: From the laboratory to the soil. Soil Biol. Biochem. 2016, 103, 117-130. [CrossRef]

199. Nautiyal, C.S. An efficient microbiological growth medium for screening phosphate solubilizing microorganisms. FEMS Microbiol. Lett. 1999, 170, 65-270. [CrossRef]

200. Becker, J.O.; Cook, E.J. Role of siderophores in suppression of Pythium species and production of increased growth response of wheat by fluorescent pseudomonads. Phytopathology 1988, 78, 778-782. [CrossRef]

201. Darma, R.; Purnamasari, I.M.; Agustina, D.; Pramudito, T.E.; Sugiharti, M. A Strong antifungal-producing bacteria from bamboo powder for biocontrol of Sclerotium rolfsii in melon (Cucumis melo var. amanta). J. Plant Pathol. Microbiol. 2016, 7, 1000334. [CrossRef]

202. Gong, M.; Wang, J.D.; Zhang, J.; Yang, H.; Lu, X.F.; Pey, Y.; EI Cheng, J.Q. Study of the antifungal ability of Bacillus subtilis strain PY-1 in vitro and identification of its antifungal substance (Iturin A). Acta Biochim. Biophys. Sin. 2006, 38, 233-240. [CrossRef]

203. Kim, P.I.; Ryu, J.; Kim, Y.H.; Chl, Y.T. Production of biosurfactant lipopeptides iturin A, fengycin and surfactin A from Bacillus subtilis CMB32 for control of Colletotrichum gloeosporioides. J. Microbiol. Biotechnol. 2010, 20, 138-145. [CrossRef]

204. Ongena, M.; Jacques, P. Bacillus lipopeptides: Versatile weapons for plant disease biocontrol. Trends Microbiol. 2008, 16, 115-125. [CrossRef] [PubMed]

205. Raaijmakers, J.M.; Vlami, M.; de Souza, J.T. Antibiotic production by bacterial biocontrol agents. Antonie Leeuwenhoek 2020, 81, 537-547. [CrossRef] [PubMed]

206. Scher, F.M.; Baker, R. Effect of Pseudomonas putida and a synthetic iron chelator on induction of soil suppressiveness to Fusarium Wilt patogena. Phytopathol. 1982, 72, 1567-1573. [CrossRef]

207. Tourè, Y.; Ongena, M.; Jacques, P.; Guiro, A.; Thonart, P. Role of lipopeptides produced by Bacillus subtilis GA1 in the reduction of grey mould disease caused by Botrytis cinerea on apple. J. Appl. Microbiol. 2004, 96, 1151-1160. [CrossRef] 
208. Zheng, M.; Shi, J.; Wang, Q.; Li, Y. Antimicrobial effects of volatiles produced by two antagonistic Bacillus strains on the anthracnose pathogen in postharvest mangos. Biol. Control 2013, 65, 200-206. [CrossRef]

209. Bargabus, R.L.; Zidack, N.K.; Sherwood, J.E.; Jacobsen, B.J. Characterisation of systemic resistance in sugar beet elicited by a non-pathogenic, phyllosphere-colonizing Bacillus mycoides, biological control agent. Physiol. Mol. Plant Pathol. 2002, 61, 289-298. [CrossRef]

210. Choudhary, D.K.; Johri, B.N. Interactions of Bacillus spp. and plants with special reference to induced systemic resistance (ISR). Microbiol. Res. 2009, 164, 493-513. [CrossRef] [PubMed]

211. Kloepper, J.W.; Ryu, C.M.; Zhang, S. Induce systemic resistance and promotion of plant growth by Bacillus spp. Phytopathology 2004, 94, 1259-1266. [CrossRef] [PubMed]

212. Ryu, C.M.; Farag, M.A.; Hu, C.H.; Reddy, M.S.; Wei, H.X.; Kloepper, J.W. Bacterial volatiles induce systemic resistance in Arabidopsis. Plant Physiol. 2004, 134, 1017-1026. [CrossRef]

213. Scotti, R.; D'Agostino, N.; Zaccardelli, M. Gene expression profiling of tomato roots interacting with Pseudomonas fluorescens unravels the molecular reprogramming that occurs during the early phases of colonization. Symbiosis 2019. [CrossRef]

214. Zaccardelli, M.; Carella, A.; Caiazzo, R.; Torre, R.; Tarantino, P.; Lahoz, E. Evaluation of two Bacillus pp. isolates inoculated on potato for antagonism against Rhizoctonia solani, plant growth promotion and provement of b-1,4-glycosidases, b-D-N-N'diacetylchitobiosidase and peroxidases Activities. Plant Pathol. J. 2004, 6, 337.

215. Nehl, D.B.; Allen, S.J.; Brown, J.F. Deleterious rhizobacteria: An integrating perspective. Appl. Soil Ecol. 1996, 5, 1-20. [CrossRef]

216. Suslow, T.V.; Schroth, M.N. Role of deleterious rhizobacteria as minor pathogens in reducing crop growth. Phytopathology 1982, 72, 111-115. [CrossRef]

217. Sahu, P.K.; Singh, S.; Gupta, A.; Singh, U.B.; Brahmaprakash, G.P.; Saxena, A.K. Antagonistic potential of bacterial endophytes and induction of systemic resistance against collar rot pathogen Sclerotium rolfsii in tomato. Biol. Control 2019, 137, 104014. [CrossRef]

218. Ling, N.; Xue, C.; Huang, Q.; Yang, X.; Xu, Y.; Shen, Q. Development of a mode of application of bioorganic fertilizer for improving the biocontrol efficacy to Fusarium wilt. Biocontrol 2010, 55, 673-683. [CrossRef]

219. Termorshuizen, A.J.; Jeger, M.J. Assessing inoculum of soilborne plant pathogens: Theory and practice in decision-making for soil disinfestation. Acta Hortic. 2014, 1044, 75-80. [CrossRef]

220. Fravel, D.R. Commercialization and implementation of biocontrol. Annu. Rev. Phytopathol. 2005, 43, 337-359. [CrossRef]

221. Martínez-Medina, A.; Roldán, A.; Pascual, J.A. Performance of a Trichoderma harzianum bentonite-vermiculite formulation against Fusarium wilt in seedling nursery melon plants. Hortic. Sci. 2009, 44, 2025-2027. [CrossRef]

222. Bernal-Vicente, A.; Ros, M.; Pascual, J.A. Increased effectiveness of the Trichoderma harzianum isolate T-78 against Fusarium wilt on melon plants under nursery conditions. J. Sci. Food Agric. 2009, 89, 827-833. [CrossRef] 